REGIONAL GROUND-WATER FLOW IN UPPER AND MIDDLE PALEOZOIC ROCKS IN SOUTHEASTERN UTAH AND ADJACENT PARTS OF ARIZONA, COLORADO, AND NEW MEXICO

by Emanuel Weiss

U.S. GEOLOGICAL SURVEY

Water-Resources Investigations Report 90-4079

Denver, Colorado

1991 


\section{U.S. DEPARTMENT OF THE INTERIOR}

MANUEL LUJAN, JR., Secretary

U.S. GEOLOGICAL SURVEY

Dallas L. Peck, Director

For additional information write to:

District Chief

U.S. Geological Survey

Box 25046, Mail Stop 415

Federal Center

Denver, CO 80225-0046
Copies of this report can

be purchased from:

U.S. Geological Survey

Books and Open-File Reports Section Box 25425, Mail Stop 517

Federal Center

Denver, CO 80225-0425 
Abstract-

Introduction-1

Purpose and scope-

General description of modeled area-

Modeled geohydrologic units-

Data sources and selection-1

Process error-

Permeability data and distribution-

Regional ground-water flow-

Recharge and discharge areas and potentiometric surfaces---

Brine flow in the limestone and dolomite aquifer-

Theory and approximations-

Flow from the brine area-

Interaquifer flow

Osmotic-pressure gradients

Chemical osmosis-

Electrical osmosis

Thermal osmosis

Conclusions about osmotic-pressure gradients-

Conclusions about the direction of interaquifer flow-

Magnitude of interaquifer flow

Boundary integral-equation method for simulation of ground-water flow----

Model of the sandstone and red-bed aquifer-

Sensitivity of the model of the sandstone and red-bed aquifer--

Model of the limestone and dolomite aquifer

Does variable-density flow need to be simulated?-_.

Summary and conclusions-

References cited-1usions

Supplemental statistical data-

A. Kriging

B. Process error and model error

C. Equivalent freshwater-head differences between aquifers-

\section{FIGURES}

Figure 1. Map showing location of study area

2. Map showing principal tectonic features of the modeled area

3. Outcrop areas of the sandstone and red-bed aquifer, mean annual precipitation on outcrops, and location of wells completed in the sandstone and red-bed aquifer--...

4. Outcrop areas of rocks of Pennsylvanian and Mississippian age and location of wells completed in the limestone and dolomite aquifer-

5. Contours of interpolated equivalent freshwater head of the sandstone and red-bed aquifer--

6. Contours of interpolated equivalent freshwater head of the limestone and dolomite aquifer- 
Figures 3-9. Maps showing--Continued:

Page

7. Contours of the standard deviation of error of the interpolated equivalent freshwater heads in the sandstone and red-bed aquifer

8. Contours of the standard deviation of error of the interpolated equivalent freshwater heads in the limestone and dolomite aquifer...

9. Dissolved-solids concentration in the ground water of the limestone and dolomite aquifer and altitude of the top of the limestone and dolomite aquifer-.--.-

10. Diagram showing variable density flow in a dipping aquifer11-16. Maps showing:

11. Possible flow paths out of the brine area based on

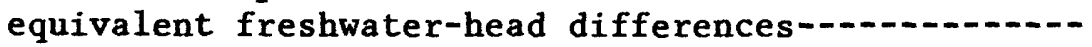

12. Interpolated equivalent freshwater heads in the sandstone and red-bed aquifer minus interpolated equivalent freshwater heads in the limestone and dolomite aquifer at grid points-...

13. Stream-surface altitudes and areas of contact between stream channels and the sandstone and red-bed

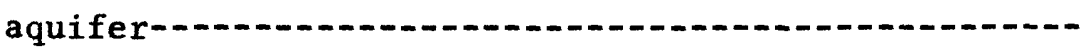

14. Model of the sandstone and red-bed aquifer using the boundary integral-equation method--

15. Contours of simulated equivalent freshwater head for the sandstone and red-bed aquifer-

16. Contours of residuals from the model of the sandstone and red-bed aquifer.-

17. Graphs showing equivalent freshwater-head residuals from the model of the sandstone and red-bed aquifer-..-

18. Graph showing semivariograms of equivalent freshwater-head data for the sandstone and red-bed aquifer-...

19. Measurements of equivalent freshwater head and statistical weights for interpolation near the northwesternmost interpolated point-

TABLES

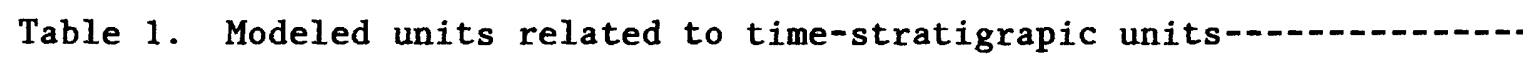

2. Statistical summary of permeability measurements for the sandstone and red-bed aquifer and limestone and dolomite aquifer-10

3. Hydrologic data along the flow paths out of the brine area--.-

4. Boundary values and calibration statistics for the model of the sandstone and red-bed aquifer-

5. Calibration statistics for the model of the limestone and
dolomite aquifer-

6. Statistical summary of equivalent freshwater-head measurements for the sandstone and red-bed aquifer and limestone and dolomite aquifer- 


\section{CONVERSION FACTORS}

Multiply

centipoise

cubic foot per second $\left(\mathrm{ft}^{3} / \mathrm{s}\right)$

foot $(f t)$

foot per mile ( $\mathrm{ft} / \mathrm{mi})$

inch (in.)

mile (mi)

millidarcy

pound per cubic foot ( $\left.1 b / f t^{3}\right)$

pound per square inch $\left(1 b / i^{2}\right)$

square foot $\left(\mathrm{ft}^{2}\right)$

square mile $\left(\mathrm{mi}^{2}\right)$
By

0.01

0.028317

0.3048

0.1894

2.540

1.609

$0.987 \times 10^{-8}$

0.01602

$1.45 \times 10^{6}$

0.0929

2.590
To obtain

gram per centimeter-second cubic meter per second meter

meter per kilometer centimeter kilometer square centimeter gram per cubic centimeter dynes per square centimeter square meter square kilometer

Temperature in degree Fahrenheit $\left({ }^{\circ} \mathrm{F}\right)$ can be converted to degree Celsius $\left({ }^{\circ} \mathrm{C}\right)$ by use of the following formula:

$$
\begin{aligned}
& { }^{\circ} \mathrm{C}=5 / 9\left({ }^{\circ} \mathrm{F}-32\right) \\
& { }^{\circ} \mathrm{F}=\left(9 / 5{ }^{\circ} \mathrm{C}\right)+32 .
\end{aligned}
$$

The following terms and abbreviations also are used in this report:

gram per liter $(\mathrm{g} / \mathrm{L})$

gram per cubic centimeter $\left(8 / \mathrm{cm}^{3}\right)$.

Sea leve1: In this report "sea level" refers to the National Geodetic Vertical Datum of 1929 (NGVD of 1929)--a geodetic datum derived from a general adjustment of the first-order level nets of both. the United States and Canada, formerly called Sea Level Datum of 1929. 


\title{
REGIONAL GROUND-WATER FLOW IN UPPER AND MIDDLE PALEOZOIC ROCKS \\ IN SOUTHEASTERN UTAH AND ADJACENT PARTS OF \\ ARIZONA, COLORADO, AND NEW MEXICO
}

By Emanuel Weiss

\begin{abstract}
A somewhat hydrologically isolated regional ground-water flow system in Paleozoic rocks that includes part of the Upper and Lower Colorado River Basins was simulated. The area of the ground-water system is about 60,000 square miles. Aquifers and confining units in rocks of Paleozoic age were defined: the sandstone and red-bed aquifer consists of all rocks of Permian age and rocks of Early Pennsylvanian age; the limestone and dolomite aquifer consists of all rocks of Mississippian and Devonian age. Between these two units is a confining unit consisting of rocks of Late Pennsylvanian age.
\end{abstract}

Permeability measurements and equivalent freshwater heads derived from drill-stem tests were examined for both aquifers. The permeability measurements of each aquifer were lognormally distributed. The geometric mean of permeability measurements for the sandstone and red-bed aquifer was 4 millidarcies per centipoise, and the geometric mean of permeability measurements for the limestone and dolomite aquifer was 424 millidarcies per centipoise. A large probability exists that geometric mean permeability of the sandstone and red-bed aquifer is one-hundredth of the geometric mean permeability of the limestone and dolomite aquifer.

Equivalent freshwater-head differences between the aquifers (the difference between the means was 521 feet) and density differences between the aquifers indicated predominantly downward flow. The only substantial, estimable osmotic-pressure gradients were chemical and were caused by differences in concentrations of dissolved solids between the aquifers in the brine area; those chemical osmotic pressure gradients tended to move water downward.

An adequate simulation of regional flow in the sandstone and red-bed aquifer was achieved by using the boundary integral-equation method. Based on the data available, the following approximations that were tested by simulation seemed to be reasonable:

(1) The aquifer has the same transmissivity everywhere.

(2) No interaquifer flow occurs for the aquifer.

(3) Ground water was the same density everywhere.

(4) A no-flow boundary occurs along the southern edge of the Uncompaghre uplift.

(5) Discharge occurs primarily from the Paleozoic outcrops in stream channels, near the center of the modeled area.

(6) Discharge occurs secondarily from the Paleozoic outcrops at Marble Canyon. 
In the flow model of the sandstone and red-bed aquifer, discharge from the Paleozoic outcrops in stream channels near the center of the modeled area was controlled by the altitude of the stream. Discharge or recharge at Dark Canyon was not part of the flow model because Dark Canyon probably is a discharge area for local flow from the Abajo Mountains. Discharge from the sandstone and red-bed aquifer in Marble Canyon was controlled by the altitudes of the Paleozoic outcrops.

A brine that has concentrations of dissolved solids as large as 374 grams per liter is present in the limestone and dolomite aquifer in the Paradox basin area. Substantial flow out of the brine area is unlikely.

Attempts to use the boundary integral-equation method to simulate reasonable flow in the limestone and dolomite aquifer failed. The principal problem in simulating accurate flow in the aquifer was simulating equivalent freshwater heads that were small enough to match measured equivalent freshwater heads. To do this, additional discharge was needed. Simulating variabledensity flow will not fulfill this need and therefore should not be a primary concern. A geostatistical interpolation of measured equivalent freshwater head indicates that, except for the boundary along the southern edge of the Uncomphgre Uplift, water generally flows from the boundaries to the center of the aquifer.

\section{INTRODUCTION}

Large supplies of ground water that range from fresh to briny occur in aquifers in rocks of Paleozoic age throughout southeastern Utah and adjacent parts of Arizona, Colorado, and New Mexico (fig. 1). The discovery of these large supplies was an indirect result of the search for oil, gas, and sites for nuclear-waste repositories. The Paradox basin (fig. 2) was the location of extensive drilling in search of oil and gas; also, it is being considered as a site for a nuclear-waste repository. Beneath some of the salt deposits is an areally extensive brine.

A study was developed to simulate regional ground-water flow in aquifers in Paleozoic rocks as part of the Upper Colorado River Basin Regional AquiferSystem Analysis (UCRB-RASA). These aquifers were selected for study because they contain large supplies of freshwater and because sufficient data exist for the development of a regional ground-water flow model. The study area was selected because it represents a somewhat hydrologically isolated regional ground-water system. An additional objective of the study was to analyze the . flow of brine.

\section{Purpose and Scope}

This report describes the regional ground-water system, in the upper and middle Paleozoic rocks in southeastern Utah and adjacent parts of Arizona, Colorado, and New Mexico, and indicates the uncertainties in the understanding of this system. A flow model and a statistical model of the ground-water system are used to organize the data and describe the ground-water system. The assumptions and results of the models are used to characterize the system. 


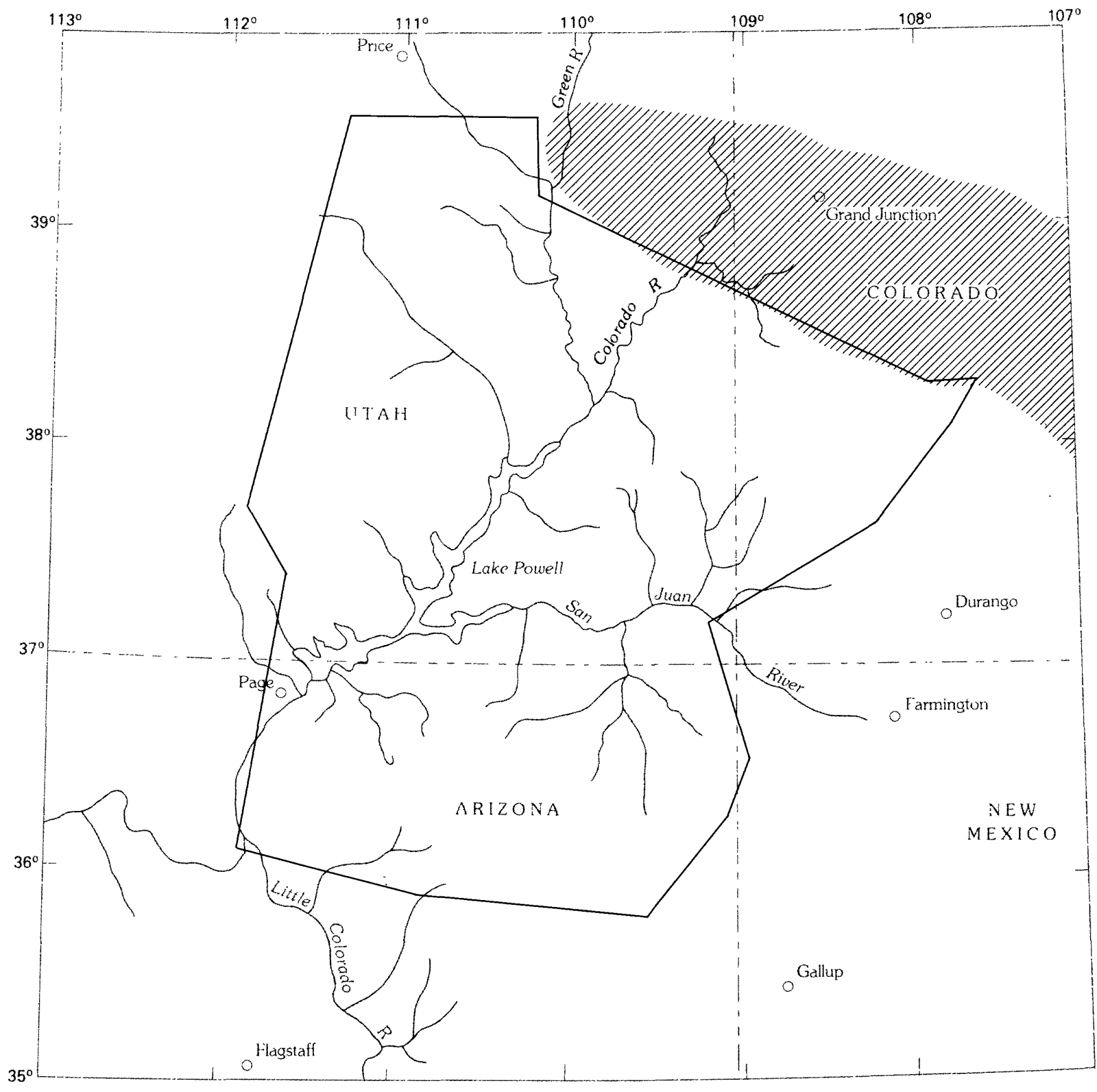

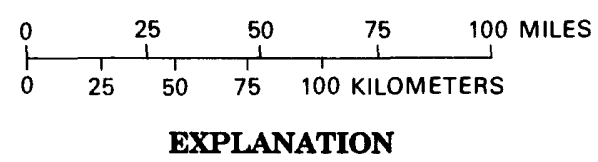

ROCKS OF PALEOZOIC AGE ABSENT (UNCOMPAHGRE UPLIFT) BOUNDARY OF THE MODELED AREA

Figure 1.--Location of study area. 

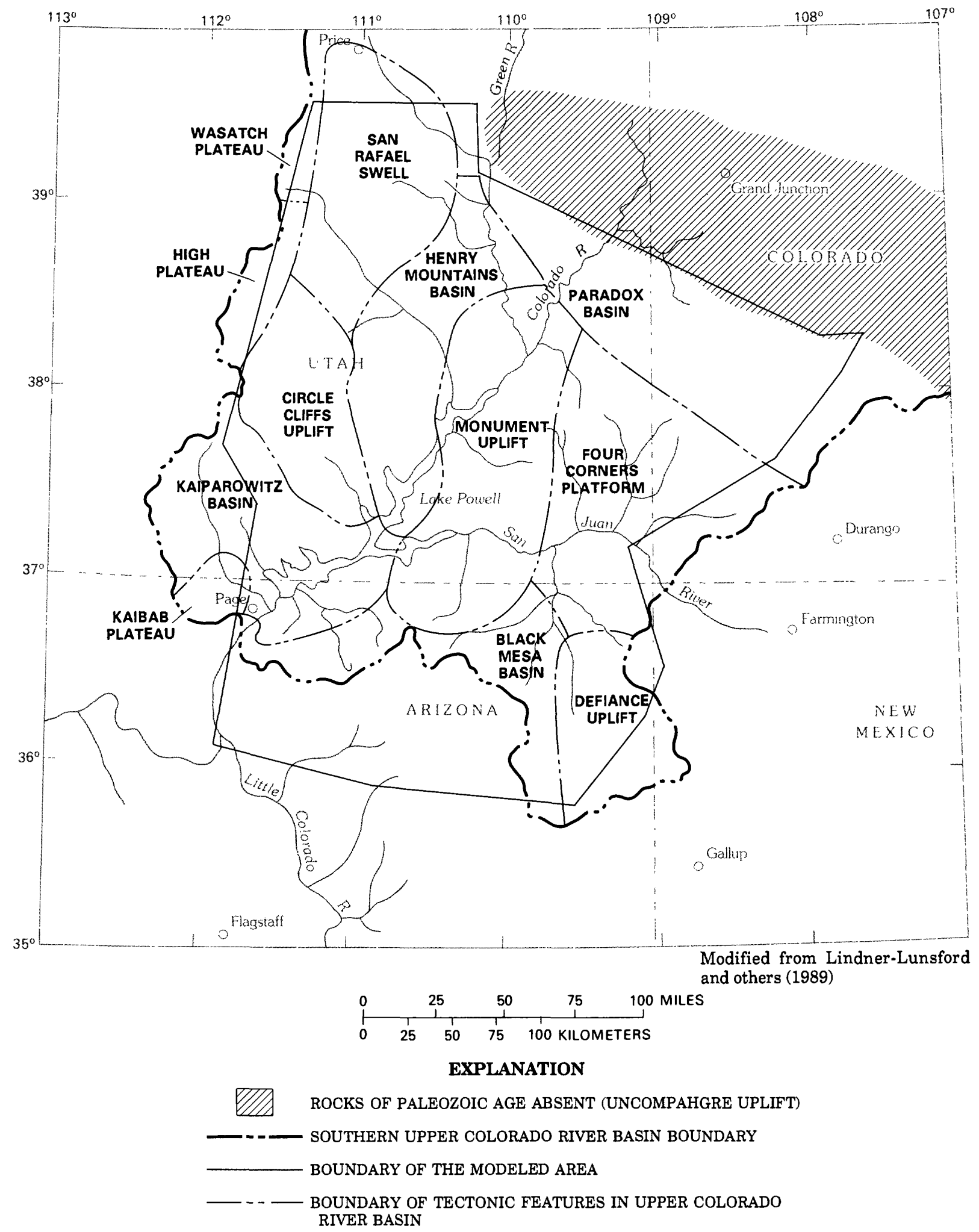

Figure 2.--Principal tectonic features of the modeled area. 
The sensitivity of flow model simulations to changes are used to determine which uncertainties in the data affect simulations most and which affect simulations least. Future hydrologic-data collection can then be directed toward decreasing uncertainties in data that substantially affect simulations.

\section{General Description of Modeled Area}

A ground-water flow system in Paleozoic rocks that includes part of the Upper and Lower Colorado River Basins and that is somewhat hydrologically isolated was defined as the system to be modeled. The modeled area is about $60,000 \mathrm{mi}^{2}$ in southeastern Utah and adjacent parts of Arizona, Colorado, and New Mexico. Relatively small quantities of ground water are used for municipal, mining, and irrigation in this sparsely populated area.

The modeled area extends from the Paleozoic outcrops of the Mogollon slope in the south to the Precambrian ancestral Uncompahgre uplift in the north. In the west, the modeled area is bounded by the Kaibab, High, and Wasatch plateaus, and, in the east, the modeled area is bounded by the Paleozoic outcrops of the Defiance and San Juan uplifts (fig. 2).

The climate ranges from arid at the lower altitudes, where annual precipitation is 6 in. or less, to semiarid at the middle altitudes, where annual precipitation ranges from 8 to 11 in. In some small areas of the high plateaus, annual precipitation is as much as 20 in.; in smaller areas of the mountains, annual precipitation can exceed $30 \mathrm{in.}$

The high plateaus and mountains are the principal recharge areas for the aquifers in Paleozoic rocks. At low altitudes, many stream channels are deep canyons that cut into the Paleozoic rocks. Many of these canyons are discharge areas for aquifers. The Colorado, Green, and the San Juan River channels are principal drainages for the surface and ground-water systems (fig. 1). Canyonlands National Park around the confluence of the Green and Colorado Rivers illustrates the prevalence of canyons in the modeled area.

\section{Modeled Geohydrologic Units}

As a part of the UCRB-RASA, the concept of geohydrologic units was used to combine several geological formations into units that are aquifers. Two previous reports on parts of this modeled area have divided the Paleozoic rocks into geohydrologic units. Hanshaw and Hill (1969) studied the hydrology of most of the modeled area and combined the Permian formations and the Mississippian and Devonian formations into two geohydrologic units; they also defined three more aquifers in the Pennsylvanian rocks. Thackston and others (1981) studied the Paleozoic rocks in the western Paradox basin and combined the Permian formations and the upper part of the youngest Pennsylvanian formation, the Honaker Trail Formation (of Wengerd and Matheny, 1958), into one geohydrologic unit; the lower part of the Honaker Trail Formation and the Paradox Formation (of Wengerd and Matheny, 1958) were defined as a confining unit. The oldest Pennsylvanian formations, the Pinkerton Trail Formation (of Wengerd and Matheny, 1958) and the Molas Formation, are combined with the Mississippian formations as an aquifer, although Thackston and others (1981) acknowledge that the Molas and Pinkerton Trail Formations are confining units in part of the western Paradox basin. 
All the modeled aquifers (table 1) and the intervening confining unit extend over the entire modeled area. The sandstone and red-bed aquifer consists of all Permian rocks plus the Rico Formation of Early Permian and Late Pennsylvanian age, and Honaker Trail Formation of Late Pennsylvanian age. The aquifer primarily consists of sandstone and shale, but generally consists of extremely variable lithology.

Table 1.--Modeled units related to time-stratigraphic units

\begin{tabular}{|c|c|c|c|}
\hline Erathem & System & Series & $\begin{array}{l}\text { Modeled } \\
\text { unit }\end{array}$ \\
\hline \multirow{8}{*}{$\begin{array}{l}\text { ○ } \\
\text { 今 } \\
\text { 今 } \\
\text { 空 } \\
\text { 岁 }\end{array}$} & \multirow{2}{*}{ Permian } & Upper & \multirow{3}{*}{$\begin{array}{l}\text { Sandstone } \\
\text { and red-bed } \\
\text { aquifer }\end{array}$} \\
\hline & & Lower & \\
\hline & \multirow{3}{*}{ Pennsylvanian } & Upper & \\
\hline & & Middle & \multirow{2}{*}{$\begin{array}{l}\text { Confining unit } \\
\text { not modeled }\end{array}$} \\
\hline & & Lower & \\
\hline & \multirow{2}{*}{ Mississippian } & Upper & \multirow{3}{*}{$\begin{array}{l}\text { Limestone } \\
\text { and dolomite } \\
\text { aquifer }\end{array}$} \\
\hline & & Lower & \\
\hline & Devonian & Upper & \\
\hline
\end{tabular}

In the Henry Mountains basin and the northern Monument Uplift areas (fig. 2), the Organ Rock Member of the Cutler Formation, a shale bed of Early Permian age, functions as a confining unit between aquifers within the sandstone and red-bed aquifer. A more detailed study of the ground-water system probably would simulate the Organ Rock Member as a confining unit.

The other Pennsylvanian rock is defined as the middle confining unit of the geohydrologic systems listed in table 1 . The confining unit consists primarily of shale and evaporite rocks. The shale beds are areally extensive throughout most of the modeled area and could contain osmotic-pressure gradients that would affect flow through them.

Throughout most of the Paradox basin (fig. 2), the confining unit contains thin layers of black shales that have large quantities of organic debris interbedded with evaporite beds. The shale layers occur at vertical intervals of 100 to $300 \mathrm{ft}$ (Baars, 1983, p. 70). Large evaporite salt deposits (predominantly halite) and associated diapirs characterize the confining unit in the Paradox basin. About one-half of the modeled area is covered by those salt deposits. 
Beneath the confining unit is the limestone and dolomite aquifer that consists of Mississippian and Devonian rocks. Data are too few to support a modeling effort of rocks older than Devonian age. For rocks older than Devonian age, Teller and Chafin (1984) recorded only two drill-stem tests in the modeled area.

The limestone and dolomite aquifer also contains minor beds of sandstone and shale. Solution channels and fractures are common in uplifted areas of that aquifer.

\section{DATA SOURCES AND SELECTION}

Data for determination of intrinsic permeability and undisturbed formation pressure in the modeled area were collated and analyzed. Intrinsicpermeability data were obtained directly from Teller and Chafin (1984); these data are discussed in the section entitled, "Permeability Data and Distribution."

Most of the equivalent freshwater heads used were calculated from drillstem tests. Generally, drill-stem tests are conducted deep below land surface where regional ground-water flow occurs. Consequently, the equivalent freshwater heads calculated from those tests are likely to be related to regional flow.

A computer tape obtained from the Petroleum Information Corporation (PI) ${ }^{1}$ in 1982 includes descriptions of thousands of drill-stem tests done in the Upper Colorado River Basin. Most of the drill-stem-test descriptions on the tape are incomplete; in the best instances, they contain shut-in pressures only for the end of the initial and final shut-in periods. More complete data containing pressure values throughout the shut-in periods obtained from Roger Hoeger (written commun., 1980) were compiled and analyzed by Teller and Chafin (1984). They derived the undisturbed formation pressure and intrinsic permeability by analysis of pressure recovery using a technique by Horner (1952). For the application of Horner's technique and a discussion of more details in the analysis of drill-stem tests, see Bredehoeft (1965). Equivalent freshwater heads from Teller and Chafin (1984) were used when the data provided sufficient coverage, and calculated values of equivalent freshwater heads from the PI-tape were used when the Teller and Chafin (1984) data were sparse or absent.

Often, drill-stem-test pressures are difficult to interpret and evaluate. Usually, insufficient time is allowed for the shut-in pressures to recover sufficiently to approximate the undisturbed aquifer pressure, especially in test-hole intervals of small permeability. To use the PI pressure data, it was necessary to decide which ending shut-in pressure best approximated the undisturbed formation pressure--the initial shut-in pressure (the pressure at the end of the initial shut-in period) or the final shut-in pressure (the pressure at the end of the final shut-in period). Bair and others (1985) indicate that the best approximation is the initial shut-in pressure. In this

${ }^{1}$ Any use of trade or firm names used in this report is for descriptive purposes only and does not constitute endorsement by the U.S. Geological Survey. 
study, the final shut-in pressure commonly was used to calculate equivalent freshwater head unless the pressure was smaller than the initial shut-in pressure by $400 \mathrm{lb} / \mathrm{in}^{2}$ or more; in that instance, the initial shut-in pressure was used. Therefore, unreasonably small final shut-in pressures were not used. If the initial or final shut-in pressure was not recorded, then the only recorded pressure was used to calculate equivalent freshwater head. The formula used to calculate equivalent freshwater head was:

$$
h=2.33 p+z
$$

where $h$ is equivalent freshwater head, in feet above sea level;

$p$ is pressure at the end of the shut-in period, in pounds per square inch; and

$z$ is altitude of the tested interval, in feet above sea level.

The constant 2.33 converts pressure to pressure head for pure water at a density of $61.8 \mathrm{lb} / \mathrm{ft}^{3}$. The formula is the same as the formula used by Teller and Chafin (1984); therefore, the equivalent freshwater heads calculated in this report from PI data can be used with those of Teller and Chafin (1984) to describe ground-water flow.

Two selections were made from the PI data: one selection required the calculated equivalent freshwater heads to be greater than the altitude halfway up the borehole from the tested interval, and the other selection required the calculated equivalent freshwater heads to be greater than the altitude threequarters of the way up the borehole from the tested interval. Each selection omitted unusually small equivalent freshwater heads because unusually small equivalent freshwater heads usually indicate inadequate pressure recovery during the drill-stem test. A comparison of the selections indicated that the data from the first selection process had no greater areal extent than the data from the second selection process. The data from the second selection process were used to supplement the data from Teller and Chafin (1984).

Requiring a minimum shut-in pressure for selection is reasonable because recharge to the aquifers in Paleozoic rocks generally occurs in the high plateaus or mountains and the drill-stem tests generally occur in the lower altitudes. Consequently, the equivalent freshwater heads from drill-stem tests usually approximate the altitudes of the recharge area. Although the selection process usually is reasonable, it might exclude valid data at specific locations.

\section{Process Error}

Usually measuring the pressure in an aquifer thousands of feet below land surface--an objective of a drill-stem test--is difficult, and results often have a large measurement error (see Bredehoeft, 1965). Besides the measurement error of drill-stem tests, errors could have occurred in the handling of tens of thousands of records of drill-stem-test data. Cross-checking was done by looking for contradictions in three sets of data: The PI tape; the data compiled by Teller and Chafin (1984); and petroleum-industry lithologic logs of boreholes. 
Besides handling and measurement error, errors occurred because vertical gradients in equivalent freshwater head were not taken into account. The difference in equivalent freshwater head between two wells (two different locations) completed in two different formations was used as if it were a difference in equivalent freshwater head between two wells in the same formation. Because many formations of large variability in hydraulic conductivity were grouped into an aquifer, errors in equivalent freshwater-head differences could be substantial.

Sometimes, equivalent freshwater heads that were measured in one formation were attributed to another formation by the onsite geologist. Several of those errors were corrected, but perhaps not all of them.

The total of all these errors, which is the difference between the value of equivalent freshwater head mapped during this study and the actual value that exists at that mapped location, perhaps at the midpoint of the aquifer, is called the process error in this report. The process error was estimated by an analysis described in the "Kriging" and "Process Error and Model Error" in the "Supplemental Statistical Data" sections at the back of this report. For the sandstone and red-bed aquifer and the limestone and dolomite aquifer, the RMS (root-mean-square) process error of this process-error distribution is $447 \mathrm{ft}$, which is about eight times the measurement error for drill-stem tests estimated for one group of tests by Bredehoeft (1965).

\section{Permeability Data and Distribution}

In this report permeability is defined as intrinsic permeability (a property of the rock) divided by dynamic viscosity (a property of the water saturating the rock); permeability is expressed in units of millidarcies per centipoise. Permeability values were compiled and determined by Teller and Chafin (1984); a staţistical summary of their data for the sandstone and red-bed aquifer and limestone and dolomite aquifer is listed in table 2 .

Table 2.--statistical summary of permeability measurements for the sandstone and red-bed aquifer and limestone and dolomite aquifer

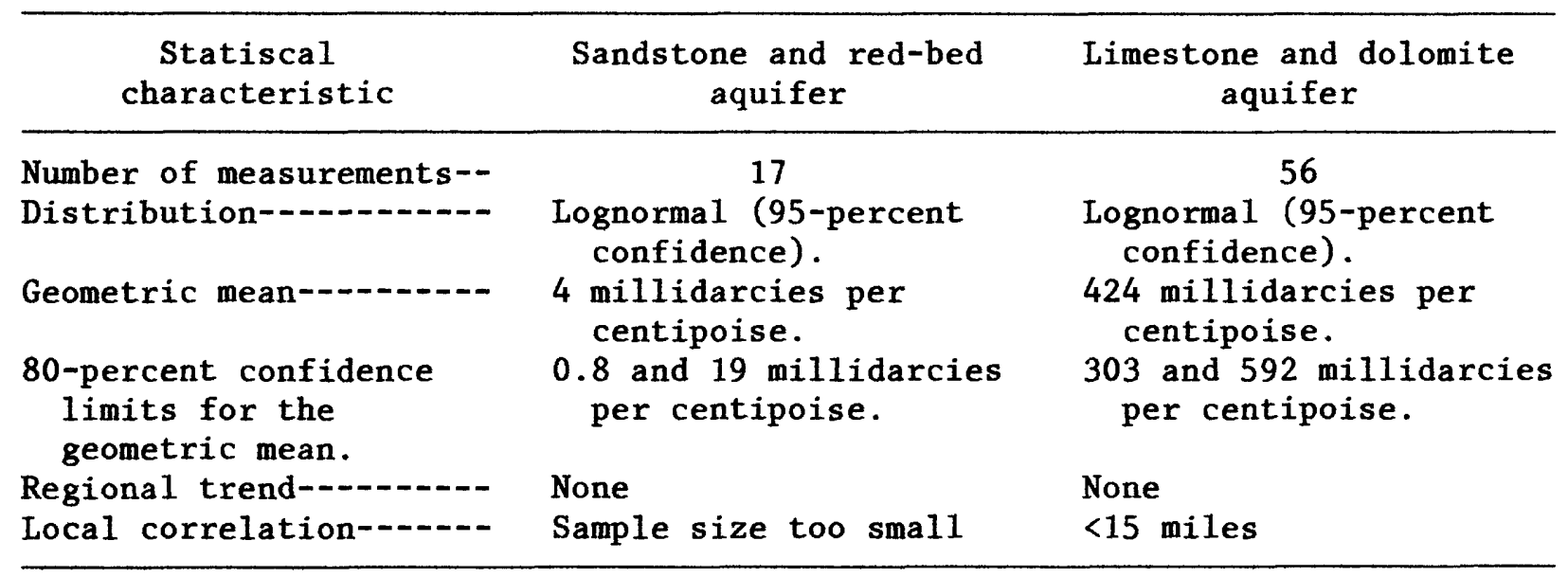


The permeability measurements were lognormally distributed for each aquifer to within a 95-percent confidence interval; the central tendency of each distribution is the geometric mean. The geometric mean of the permeability measurements is 4 millidarcies per centipoise for the sandstone and red-bed aquifer and 424 millidarcies per centipoise for the limestone and dolomite aquifer. The 80-percent confidence limits for the geometric mean of the permeability of the sandstone and red-bed aquifer are 0.8 and 19 millidarcies per centipoise, which indicates that if a large number of samples containing 17 measurements were taken and 80-percent confidence limits were calculated for each sample, then approximately 80 percent of the calculated limits would contain the geometric mean of the population. The population is all possible permeability measurements in the sandstone and red-bed aquifer. The geometric means and confidence limits for both aquifers characterize poor aquifers (Todd, 1959, fig 3.4).

This paragraph explains the last line of table 2. Natural logarithms of values of permeability of the limestone and dolomite aquifer were used to make empirical semi-variograms; not enough measurements of the sandstone and red-bed aquifer existed to make a valid semi-variogram (see subsection B, "Process Error and Model Error" in the "Supplemental Statistical Data" section at the back of this report for a definition of semi-variogram and nugget). Three empirical semi-variograms--an isotropic, an east-west, and a northsouth--were made. Each was interpreted as a pure nugget having a sill of approximately 3.5 ; the variance of the logarithms of permeability is 3.8 . The approximate agreement between the sills and the variance supports the use of semi-variograms. Because each semi-variogram is a pure nugget, no spatial autocorrelations of the logarithms of permeability were present; thus, the best prediction of permeability at any point in the limestone and dolomite aquifer is the geometric mean of all the permeability measurements, and no spatial variation in permeability is justified on the basis of data compiled by Teller and Chafin (1984).

\section{REGIONAL GROUND-WATER FLOW}

Regional ground-water flow is along long flow paths, and local groundwater flow is along short flow paths. A flow path extends from a recharge area to a discharge area. In this report, regional flow commonly is along paths that are longer than $25 \mathrm{mi}$. Usually regional flow is in the deep parts of an aquifer, except near recharge and discharge areas.

In both aquifers being considered here, regional flow is from the east and west of the modeled area toward the center of the modeled area near the Colorado River. In addition, regional ground-water flow moves north from Arizona in the limestone and dolomite aquifer. On the southern edge of the Uncompahgre uplift, both aquifers end against Precambrian quartzite, which forms a barrier to flow. 
Recharge and Discharge Areas and Potentiometric Surfaces

Outcrop areas and location of wells completed in the two aquifers are shown in figures 3 and 4 . Mean annual precipitation on outcrops also is shown in figure 3. Outcrops around the boundaries of the modeled area are potential recharge areas; canyons near the center of the modeled area are areas with potentially substantial discharge.

Large areas of the sandstone and red-bed aquifer are exposed near the center of the modeled area; in those areas, canyons cut deeply into the sandstone and red-bed aquifer almost into the limestone and dolomite aquifer. In the canyons, ground-water usually discharges from the exposed sandstone and red-bed on the walls of the canyons. Discharge from rocks of Permian and Pennsylvanian age has been observed in the canyons of southeastern Utah, but discharge from older rocks has not been observed (Dunbar and Thackston, 1985, p. 17-18). For the sandstone and red-bed aquifer, precipitation on the well-defined outcrop areas in the plateaus in the south and in the mountains in the east of the modeled area (fig. 3) accounts for much of the aquifer recharge. For the limestone and dolomite aquifer, precipitation on small outcrops in the mountains in the eastern part of the modeled area accounts for the westward flow. The absence of other outcrop areas indicates that the limestone and dolomite aquifer probably, receives most of its recharge from outside the modeled area and from upward and downward leakage. Near the western boundary of the modeled area, where the sandstone and red-bed aquifer does not crop out, the sources of recharge to it probably are from outside the modeled area and from leakage. If ground water is derived from outside the modeled area, the source of that water west of the modeled area is difficult to identify. Precipitation on the plateaus might move downward through faults to recharge both aquifers near the western boundary.

Contours of the interpolated equivalent freshwater heads for the sandstone and red-bed aquifer are shown in figure 5. Interpolation was done by kriging (see subsection A, "Kriging" in the "Supplemental Statistical Data" section at the back of this report) that used two equivalent freshwater heads at the Marble Canyon, equal to the altitude of Paleozoic rock outcrops there. The contours indicate that regional flow is from the sides of the modeled area toward the center, and a small regional flow is toward the south out of the modeled area. A comparison of the equivalent freshwater-head gradients in the east with those in the west indicates larger gradients in the east; that difference in gradients could be the result of a larger flow of water from the outcrops in the mountains of Colorado and a smaller flow of water from the west because of an absence of outcrops near the western boundary of the modeled area (fig. 5). Near the center of the modeled area where large exposures of the sandstone and red-bed aquifer occur, many springs also occur that have been ignored in the interpolation calculation. Thackston and others (1981) used spring altitudes, which indicate included local flow, to draw potentiometric contours for the sandstone and red-bed aquifer in the center of the modeled area (fig. 5). Many of the contours of 7,000 ft or larger are conjecture. In figure 5, interesting similarities and differences between the contours of Thackston and others (1981) and the interpolated contours are shown. On the western side of the Colorado River, the contours are consistent; on the eastern side of the Colorado River, the shape of the contours is similar, but the areas of local recharge, indicated by the contours of Thackston and others (1981), are absent from the interpolated contours. 

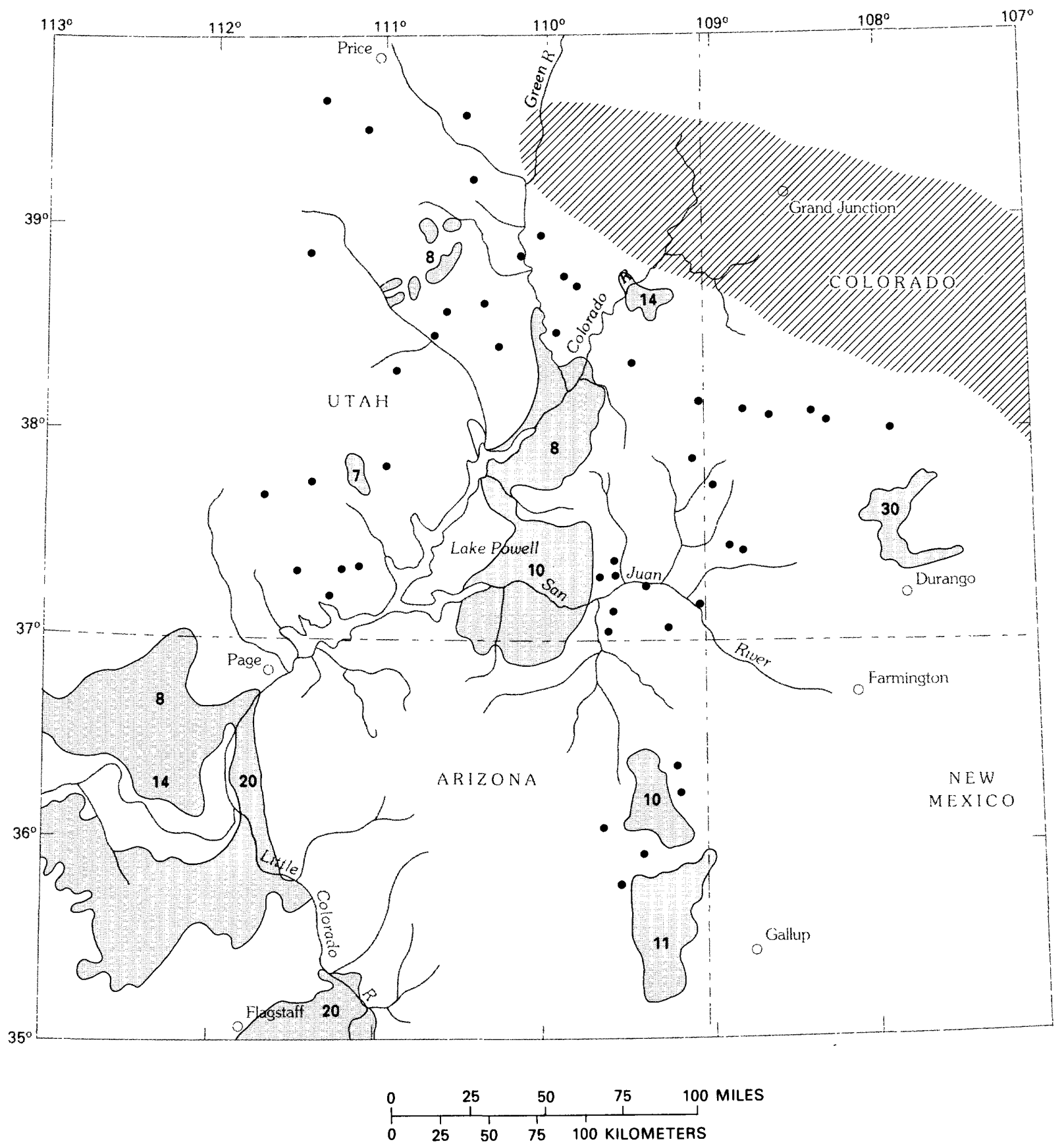

EXPLANATION

ROCKS OF PALEOZOIC AGE ABSENT (UNCOMPAHGRE UPLIFT)

OUTCROP OF UPPER PALEOZOIC ROCKS

- well location

7 AVERAGE ANNUAL PRECIPITATION ON OUTCROP, IN INCHES

Figure 3.--Outcrop areas of the sandstone and red-bed aquifer, mean annual precipitation on outcrops, and location of wells completed in the sandstone and red-bed aquifer (modified from Weiss, 1987). 


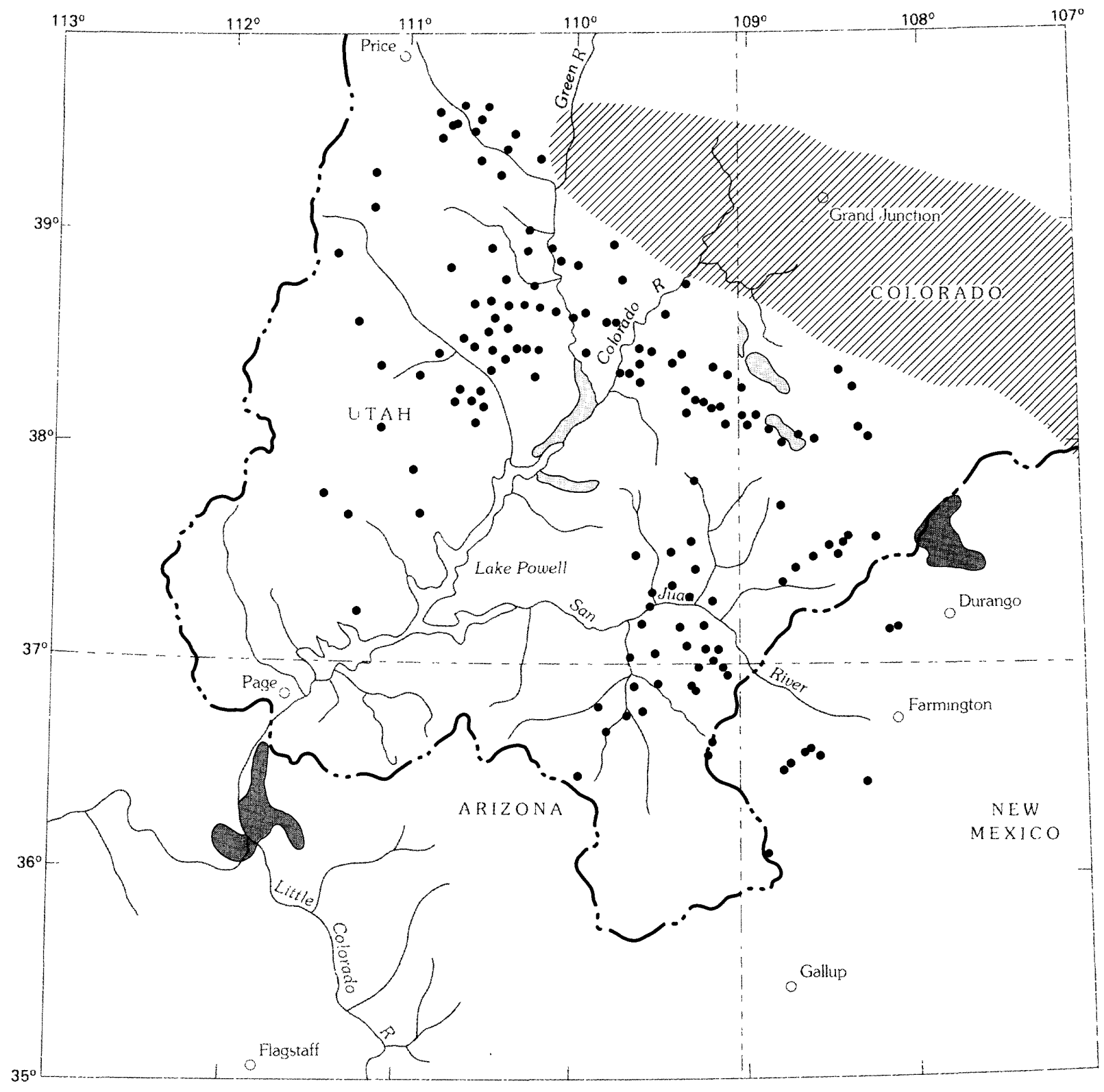

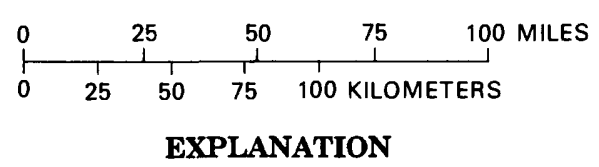

EDA ROCKS OF PALEOZOIC AGE ABSENT (UNCOMPAHGRE UPLIFT)

$\square$ OUTCROP OF PENNSYLVANIAN ROCKS

OUTCROP OF MISSISSIPPIAN ROCKS

- - SOUTHERN UPPER COLORADO RIVER BASIN BOUNDARY

- WELl LOCATiON

Figure 4.--Outcrop areas of rocks of Pennsylvanian and Mississippian age and location of wells completed in the limestone and dolomite aquifer. 

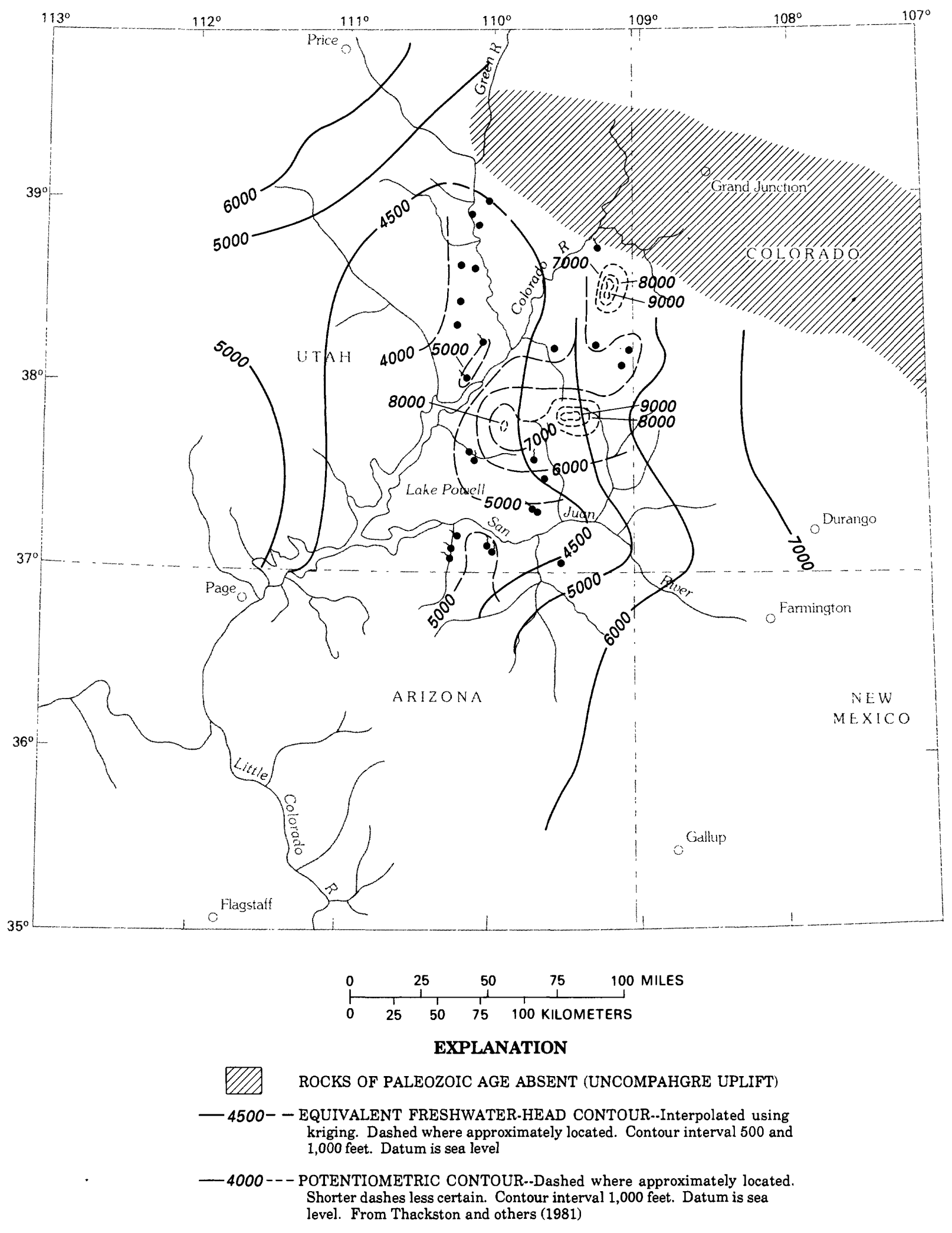

- WELL WITH DRILL-STEM-TEST DATA-.From Thackston and others (1981)

- SPRING--From Thackston and others (1981)

Figure 5.--Contours of interpolated equivalent freshwater head of the sandstone and red-bed aquifer (modified from Weiss, 1987). 
Contours of interpolated equivalent freshwater heads for the limestone and dolomite aquifer indicate that ground water moves from the sides toward the center of the modeled area (fig. 6). Flow that originates near the intersection of latitude $37^{\circ} 15^{\prime}$ and longitude $111^{\circ} 15^{\prime}$ and that moves toward the south indicates that ground-water discharges somewhere south of the modeled area. However, most discharge from the limestone and dolomite aquifer is near the center of the modeled area. In the brine area, contours of equivalent freshwater heads do not necessarily indicate direction of flow. The "Brine Flow in the Limestone and Dolomite Aquifer" section explains the dynamics of brine flow.

An interpolation error is calculated (see subsection B, "Process Error and Model Error" in the "Supplemental Statistical Data" section at the back of this report). Contours of the standard deviations of the errors of the interpolated equivalent freshwater heads are shown in figures 7 and 8 . The error contours range from 800 to $600 \mathrm{ft}$ for the sandstone and red-bed aquifer (fig. 7) and from 1,000 to $600 \mathrm{ft}$ for the limestone and dolomite aquifer (fig. 8). For both aquifers, the errors are large near the boundaries of the modeled area, and the errors are large in the south-central part of the modeled area where data are sparse.

\section{Brine Flow in the Limestone and Dolomite Aquifer}

Because of the large concentrations of dissolved solids in brines, brine densities are substantially greater than freshwater densities. The purpose of this section is to determine how density differences in and around the brine area affect ground-water flow.

A dense brine exists in the limestone and dolomite aquifer along the southern boundary of the Uncompahgre uplift (fig. 9). In the area of the brine (Paradox basin), the top of the limestone and dolomite aquifer forms an elongated bow1-like surface that is approximately bisected by the Precambrian quartzite of the ancestral Uncompahgre uplift. Blocked from northeasterly movement by an impermeable wall of quartzite, the dense brine would almost be stationary at the bottom of the dipping aquifer if not driven elsewhere by equivalent freshwater-head gradients or other forces. If the brine is stationary, no mixing or dispersion will occur. The primary mechanism of spreading would be molecular diffusion, which usually is a much smaller effect than dispersion in flowing ground water. To determine if areal equivalent freshwater-head gradients can drive brine from the brine area, a discussion of Darcy's law for a variable-density liquid follows. 

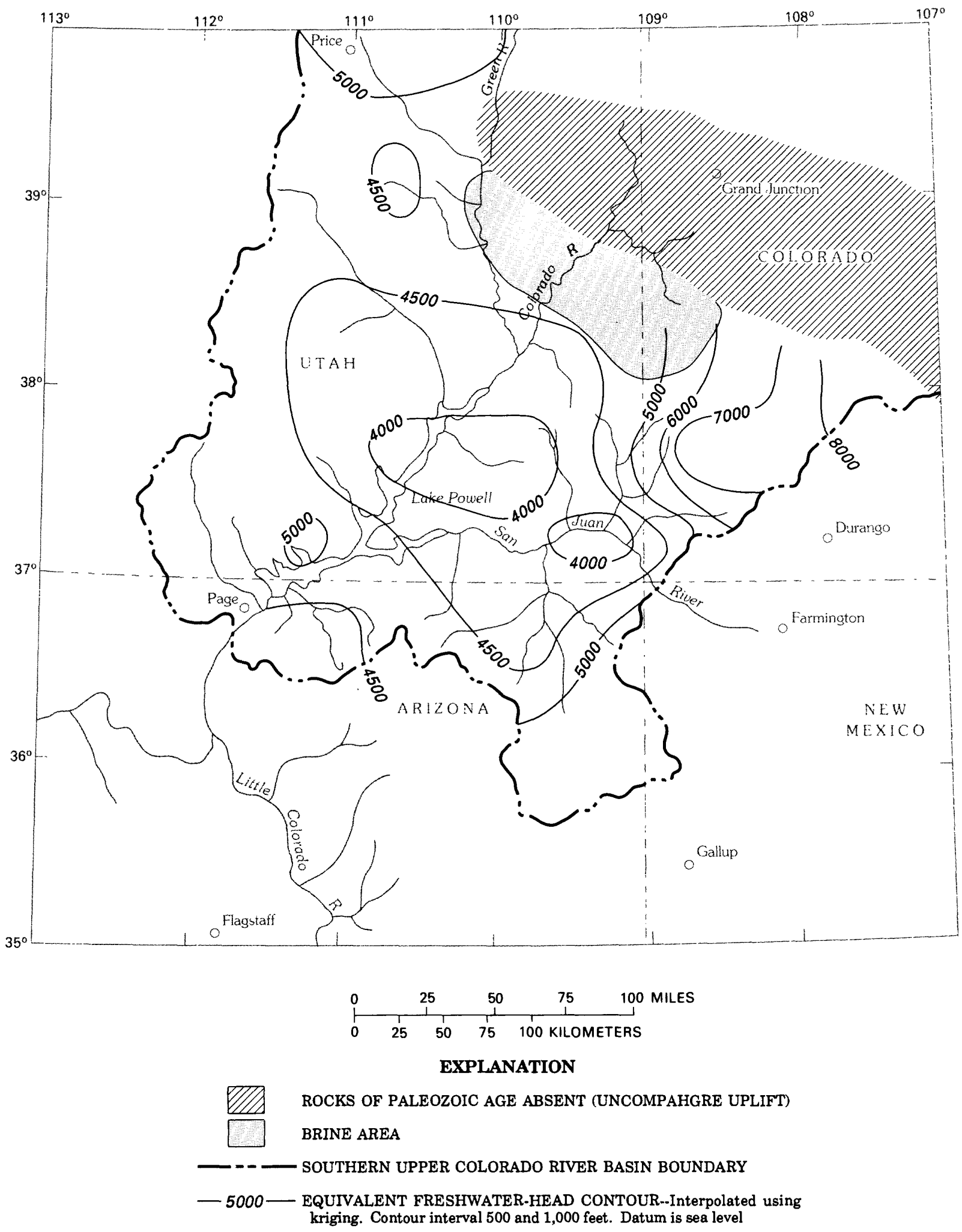

Figure 6.--Contours of interpolated equivalent freshwater head of the limestone and dolomite aquifer. 

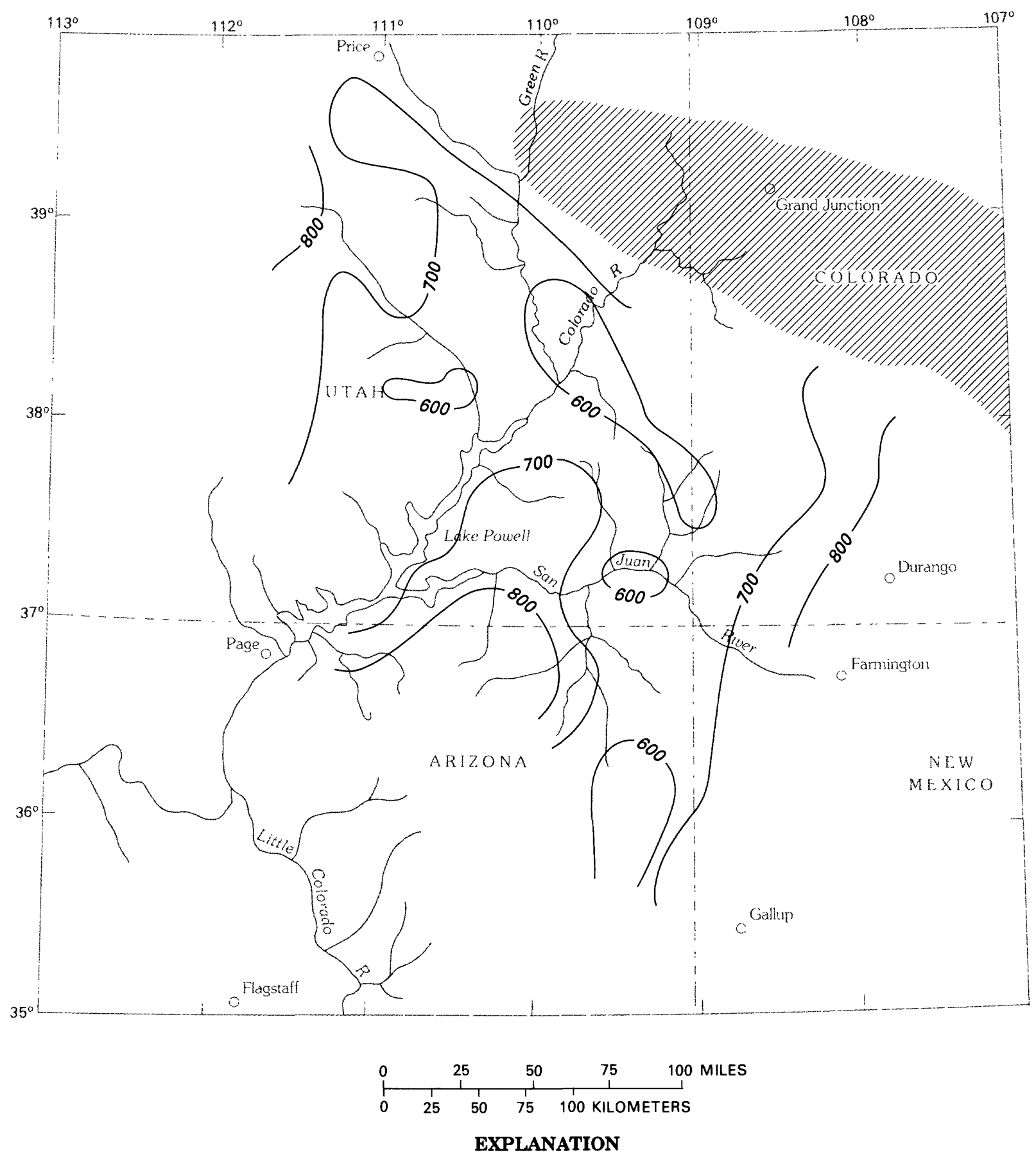

UIA ROCKS OF PALEOZOIC AGE ABSENT (UNCOMPAHGRE UPLIFT)

- 800- STANDARD DEVIATION CONTOUR--Contour interval 100 feet

Figure 7.--Contours of the standard deviation of error of the interpolated equivalent freshwater heads in the sandstone and red-bed aquifer. 

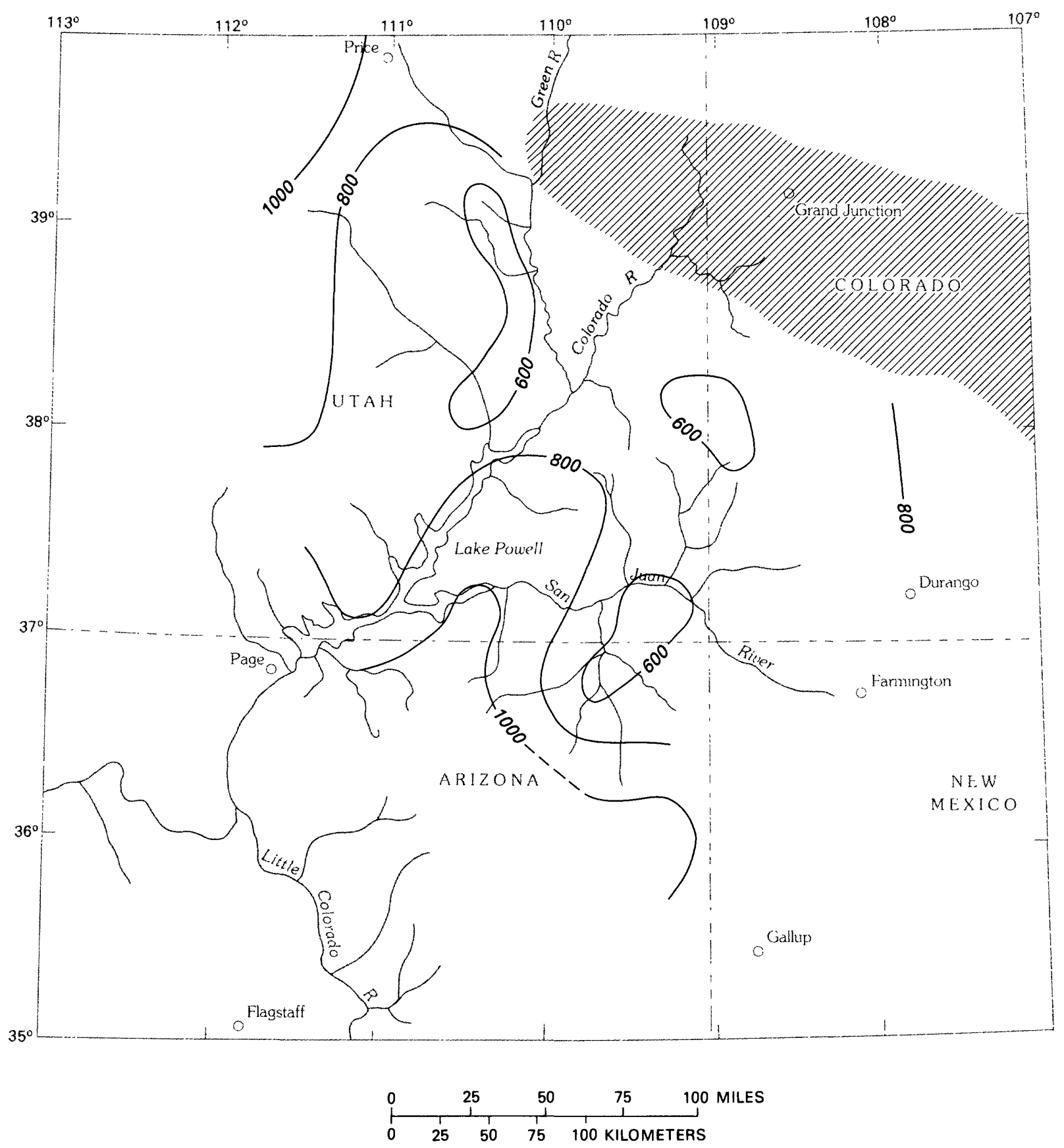

EXPLANATION

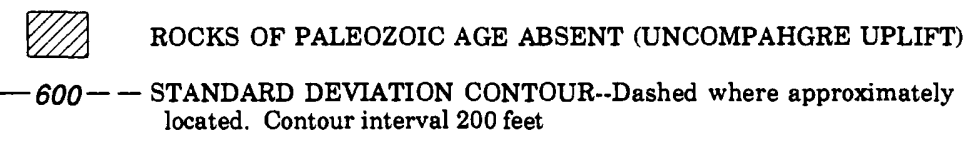

Figure 8.--Contours of the standard deviation of error of the interpolated equivalent freshwater heads in the limestone and dolomite aquifer. 

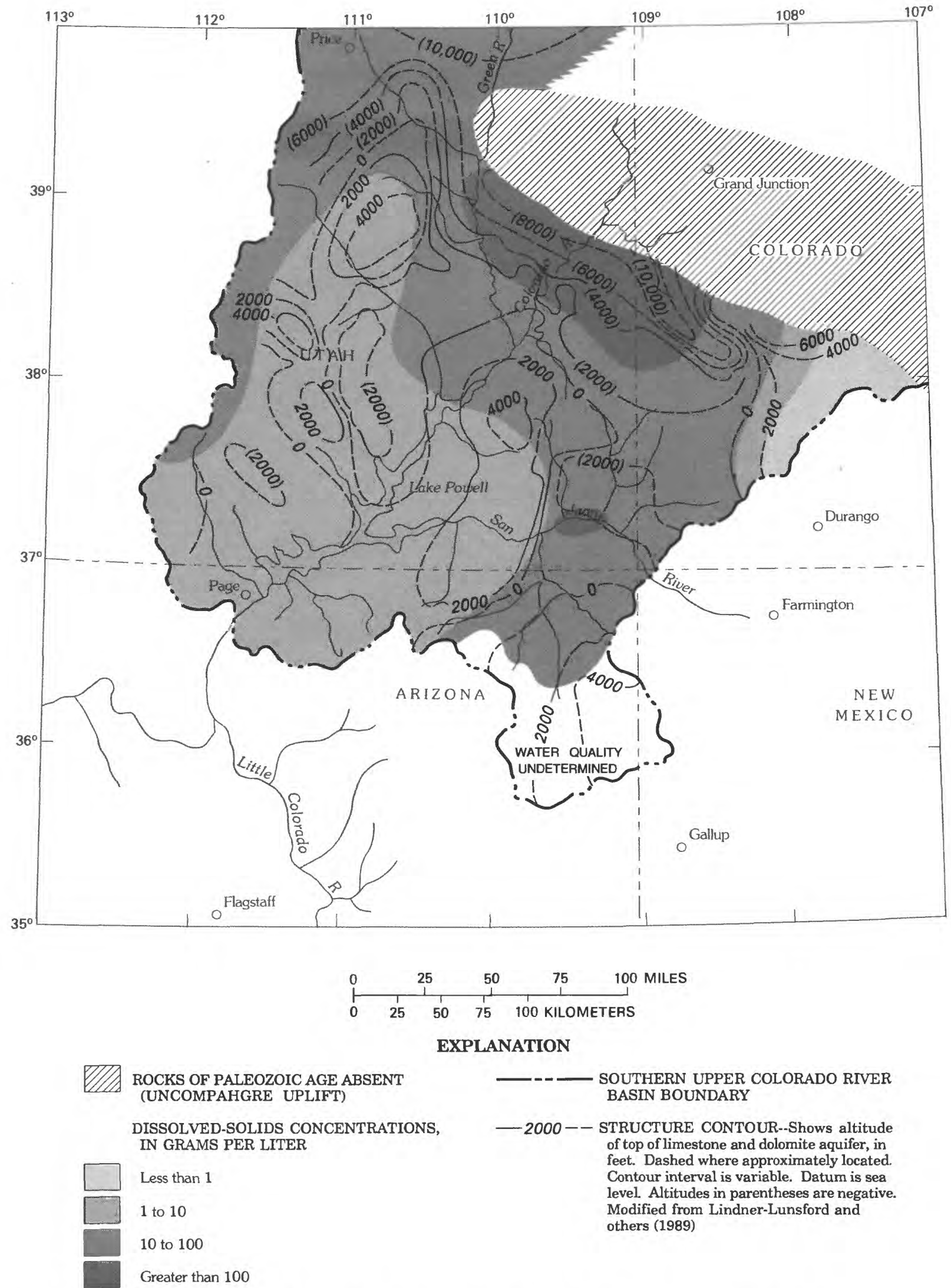

ROCKS OF PALEOZOIC AGE ABSENT (UNCOMPAHGRE UPLIFT)

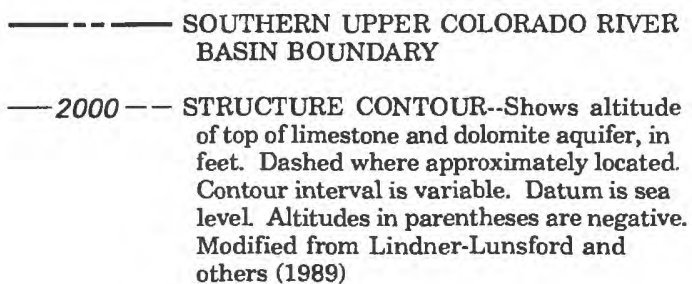

DISSOLVED-SOLIDS CONCENTRATIONS, IN GRAMS PER LITER

Less than 1

1 to 10

10 to 100

Greater than 100

Figure 9.--Dissolved-solids concentration in the ground water of the limestone and dolomite aquifer and altitude of the top of the limestone and dolomite aquifer. 
If only equivalent freshwater-head gradients and density differences are assumed to affect the areal flow in the brine area, then to determine areal flow, Darcy's law for a variable-density liquid needs to be considered (Scheidegger, 1974):

$$
\bar{q}=-\frac{k}{\mu}(\nabla p-\rho \bar{g})
$$

where $\bar{q}$ is specific discharge vector, $\mathrm{L} / \mathrm{T}$;

$k$ is the permeability, $L^{2}$;

$\mu$ is the viscosity, M/LT;

$p$ is the pressure, $M / L^{2}$;

$\rho$ is the density, $M / L^{3}$; and

$\bar{g}$ is the acceleration of gravity vector, $\mathrm{L} / \mathrm{T}^{2}$.

This can be rewritten in terms of equivalent freshwater head, $h$, as:

$$
\bar{q}=-\rho_{o / \rho} k\left(\nabla h+\frac{\Delta \rho}{\rho_{o}} \hat{k}\right) ;
$$

where $K$ is $k \rho g / \mu$ the hydraulic conductivity, $\mathrm{L} / \mathrm{T}$;

$h$ is $p / \rho_{o} g+z, L$;

$\rho_{0}$ is freshwater density, $M / L^{3}$;

$z$ is the elevation at which head is measured, $L$;

$\Delta \rho$ is $\rho-\rho_{0}, M / L^{3}$; and

$\hat{k}$ is a unit vector pointing upward.

In equation 3 , the equivalent freshwater-head gradient and density difference are in separate terms; consequently, each force can be calculated separately and compared.

Because a search for flow paths out of the brine will be the only application of the above formula, only instances where an equivalent freshwaterhead gradient is driving the brine upslope ( $\nabla h$ pointing downslope) will be considered. The component of specific discharge moving up a slope that makes an angle " $\theta$ " with the horizontal, is:

$$
q=-\rho_{0 /} K\left(H+\frac{\Delta \rho}{\rho_{0}} \sin \theta\right),
$$

where $H$ is the component of $H$ along the slope (fig. 10).

For brine to flow upslope:

$$
H>\frac{\Delta \rho}{\rho_{0}} \sin \theta .
$$


The inequality applies at any point in the liquid, but $H$ and $\sin \theta \operatorname{cannot}$ be obtained at points; consequently, an approximation is needed. After approximating $H$ and $\sin \theta$ as ratios of differences, the above inequality can be put in the following form:

$$
\frac{\Delta h}{\Delta a}>\Delta \rho / \rho_{0}
$$

where $\Delta h$ is the difference between the equivalent freshwater heads at the ends of the slope or at the ends of the flow path;

$\Delta a$ is the difference between the altitudes of the ends of the slope; and

$\Delta \rho$ is the difference between the average density of ground water on the slope and the density of pure water.

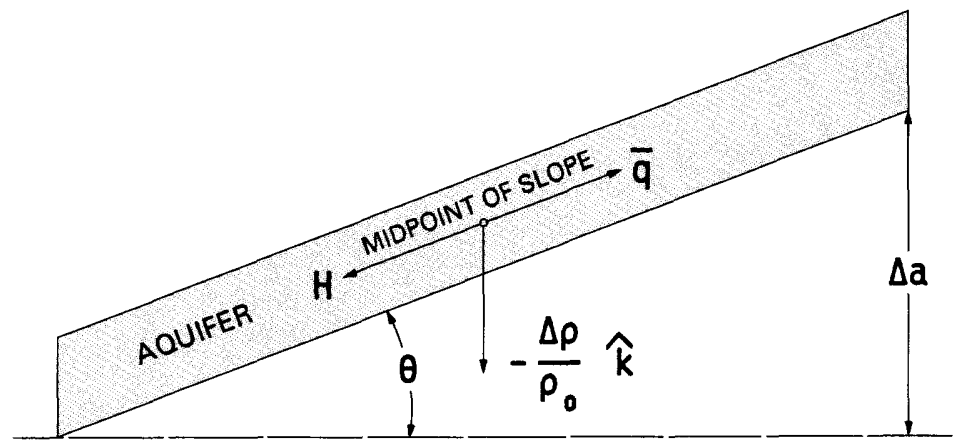

\section{EXPLANATION}

$\bar{q}$ SPECIFIC DISCHARGE UPSLOPE, LENGTH PER TIME

H COMPONENT OF THE GRADIENT OF THE EQUIVALENT FRESHWATER HEAD, ALONG THE SLOPE, DIMENSIONLESS

$\triangle a$ CHANGE IN ALTITUDE OF SLOPE, LENGTH

$\theta$ ANGLE OF SLOPE TO HORIZONTAL, IN DEGREES

$\rho_{0}$ REFERENCE DENSITY FOR GROUND WATER, 61.8 POUNDS PER CUBIC
FOOT, MASS PER LENGTH CUBED

$\Delta \rho$ DENSITY OF GROUND WATER MINUS REFERENCE DENSITY, MASS PER LENGTH CUBED

$\hat{k}$ UNIT VECTOR POINTING UPWARD, DIMENSIONLESS

Figure 10.--Variable density flow in a dipping aquifer.

Flow paths are defined from grid points in the brine to grid points outside the brine. Of the possible flow paths out of the brine, defined by the grid points, only 11 paths have an equivalent freshwater-head difference sufficient to cause flow out of the brine area. The equivalent freshwater heads shown in figure 6 are the equivalent freshwater heads used to calculate $\Delta h$ for the flow paths of figure 11. The altitudes of the end points of the flow paths used to calculate $\Delta a$ are taken from figure 9 . 

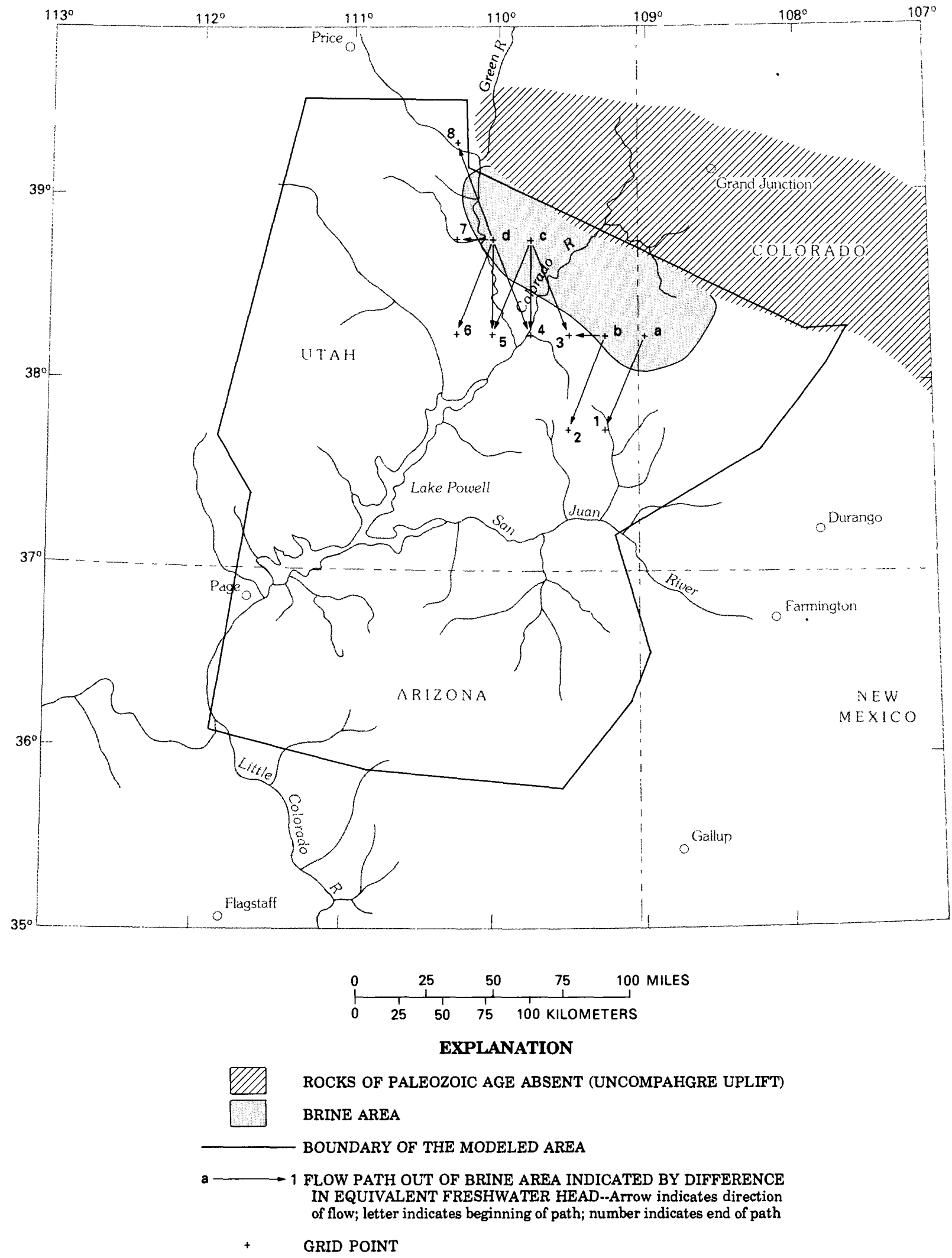

Figure 11.--Possible flow paths out of the brine area based on equivalent freshwater-head differences. 
No direct measurements of density are available; the density of any sample of brine depends on its composition, which varies throughout the brine area. Because densities of sodium chloride water solutions have been compiled by Potter and Brown (1977) for a wide range of sodium chloride concentrations, temperatures, and pressures and because the variation of brine density with composition is not known, the density of the brine is assumed to be the same as the density of a sodium chloride solution of the same concentration of dissolved solids. Justification for this assumption is the fact that the dominant ions of the brine are sodium and chloride, and chloride is by far the dominant anion.

South of the Uncompahgre uplift, the limestone and dolomite aquifer is buried under as much as 16,000 $\mathrm{ft}$ of sedimentary rock. Hydrologic data collected from this part of the aquifer are variable and uncertain. Brine in this aquifer is at temperatures as high as $212^{\circ} \mathrm{F}$ and contains dissolvedsolids concentrations that vary from approximately $100 \mathrm{~g} / \mathrm{L}$ to as much as $374 \mathrm{~g} / \mathrm{L}$; the altitude of the top of the aquifer varies from sea level to $12,000 \mathrm{ft}$ below sea level, and the vertical temperature gradient varies from $0.8^{\circ} \mathrm{F} / 100 \mathrm{ft}$ to $1.2^{\circ} \mathrm{F} / 100 \mathrm{ft}$. The altitude of the top of the aquifer is uncertain over most of the area (dashed contours in fig. 9), and the areal distribution of dissolved solids is uncertain.

The large uncertainties and errors make an accurate determination of the equivalent freshwater head, density, and altitude of the top of the aquifer impossible in the brine area; therefore, estimated values will be used. Furthermore, vertical variation of these three factors for ground water within the limestone and dolomite aquifer cannot be determined because few measurements exist along the vertical dimension. As a result, in the following discussion it is assumed that all flow takes place in the surface at the top of the limestone and dolomite aquifer. That two-dimensional approximation commonly is made in simulations of ground-water flow and ground-water transport, but it is less applicable to variable-density flow. However, it offers a simple, reasonable approximation to a complex problem for which not enough data exist to support complex analysis.

To compute the density of the brine along the flow paths, a mid-range value of $200-\mathrm{g} / \mathrm{L}$ dissolved solids was assumed; this value corresponds to a 4.28-molal solution of sodium chloride at laboratory conditions and is in the middle of the $100-300-g / L$ range of the brine area (fig. 9). For an iterative method for the calculation of molality from concentration of sodium chloride solutions, see Weiss (1982, p. 42).

For all flow paths shown in figure 11, an average altitude of $-2,600 \mathrm{ft}$ is used; an average depth of burial is estimated to be $7,000 \mathrm{ft}$; an average vertical temperature gradient is estimated to be $1^{\circ} \mathrm{F} / 100 \mathrm{ft}$; and a mean annual surface temperature is estimated to be $52^{\circ} \mathrm{F}$. The temperature of brine under these conditions is $122^{\circ} \mathrm{F}$.

Pressure has the smallest effect on the density. To calculate pressure, it was assumed that average equivalent freshwater head was 4,500 ft along each path and the average altitude of the mid-point of the flowpaths was $-2,600 \mathrm{ft}$. A pressure of approximately 200 bars was calculated by using this average equivalent freshwater head and altitude in the definition of equivalent freshwater head. 
Using table 11 of Potter and Brown (1977) for a 4.5 molal solution of sodium chloride and using 200 bars of pressure and $50^{\circ} \mathrm{C}$, a value of $1.146 \mathrm{~g} / \mathrm{cm}^{3}$ is determined for the average density of brine along all paths.

The density of freshwater was $0.990 \mathrm{~g} / \mathrm{cm}^{3}$, which corresponded to the weight density of $61.8 \mathrm{lb} / \mathrm{ft}^{3}$ (see "Conversion Factors" section) used in Teller and Chafin (1984); (see "Data Sources and Selection" section). When these values of density were used in the density ratio, $\frac{\Delta p}{\rho_{0}}$, the value was 0.157 , which is in the last column in table 3 .

Table 3.--Hydrologic data along the flow paths out of the brine area

[Flowpaths shown in figure 11; $\Delta h$ is the difference between the equivalent freshwater heads at the ends of the slope; $\Delta a$ is the difference between the altitudes of the ends of the slope; $\Delta p$ is the difference between the average density of ground water on the slope and the density of freshwater; and $\rho_{0}$ is the density of freshwater (61.8, in pounds per cubic foot)]

\begin{tabular}{|c|c|c|c|c|c|c|c|}
\hline \multicolumn{6}{|c|}{ Flow path } & \multicolumn{2}{|c|}{ Inequality } \\
\hline & tart & & & End & & $\Delta h$ & $\Delta \rho$ \\
\hline $\begin{array}{c}\text { Equivalent } \\
\text { freshwater } \\
\text { head } \\
\text { (feet) }\end{array}$ & Point & $\begin{array}{l}\text { Alti- } \\
\text { tude } \\
\text { (feet) }\end{array}$ & $\begin{array}{c}\text { Equivalent } \\
\text { freshwater } \\
\text { head } \\
\text { (feet) }\end{array}$ & Point & $\begin{array}{l}\text { Alti- } \\
\text { tude } \\
\text { (feet) }\end{array}$ & $\Delta a$ & $\begin{array}{c}\rho \\
\text { (estionate } \\
\text { for all } \\
\text { flow paths) }\end{array}$ \\
\hline 4,850 & (a) & $-4,000$ & 4,679 & (1) & 0 & 0.043 & 0.157 \\
\hline 4,619 & (b) & $-3,000$ & $\begin{array}{l}4,008 \\
4,468\end{array}$ & $\begin{array}{l}(2) \\
(3)\end{array}$ & $\begin{array}{r}0 \\
-2,000\end{array}$ & $\begin{array}{l}.204 \\
.151\end{array}$ & $\begin{array}{l}.157 \\
.157\end{array}$ \\
\hline 4,603 & (c) & $-6,000$ & $\begin{array}{l}4,466 \\
4,416 \\
4,314\end{array}$ & $\begin{array}{l}(3) \\
(4) \\
(5)\end{array}$ & $\begin{array}{r}-2,000 \\
0 \\
1,500\end{array}$ & $\begin{array}{l}.034 \\
.031 \\
.039\end{array}$ & $\begin{array}{l}.157 \\
.157 \\
.157\end{array}$ \\
\hline 4,762 & (d) & $-4,000$ & $\begin{array}{l}4,416 \\
4,314 \\
4,158 \\
4,615 \\
4,716\end{array}$ & $\begin{array}{l}(4) \\
(5) \\
(6) \\
(7) \\
(8)\end{array}$ & $\begin{array}{r}0 \\
1,500 \\
0 \\
-2,000 \\
-6,000\end{array}$ & $\begin{array}{l}.087 \\
.081 \\
.151 \\
.074 \\
.023\end{array}$ & $\begin{array}{l}.157 \\
.157 \\
.157 \\
.157 \\
.157\end{array}$ \\
\hline
\end{tabular}


The concentrations of dissolved solids in figure 9 are mostly in the range 1 to $10 \mathrm{~g} / \mathrm{L}$. A transition zone exists around the brine area that has concentrations of dissolved solids in the range 10 to $100 \mathrm{~g} / \mathrm{L}$. According to the following analysis, flow of dissolved solids that is caused by differences in equivalent freshwater head and density of water occurs along only two flow paths from the brine area.

Data describing the eleven flow paths, which are shown in figure 11 , are listed in table 3 . One of these flow paths, the one from point $d$ to point 8 , is downslope from the brine area; however, the altitudes at the ends of that flow path are in doubt (fig. 9). Along this flow path, brine probably flows from the brine area.

For the other flow paths, if $\Delta \mathrm{h} / \Delta \mathrm{a}$ is greater than $\Delta \rho / \rho_{\mathrm{o}}$, flow will be upslope, to the transition zone and from the brine area. That condition only is satisfied along the flow path from point $b$ to point 2 (table 3 ). To determine the magnitude of onsite flow relative to the hypothetical flow only due to equivalent-freshwater head difference, use the information in table 3 .

$$
\frac{\text { onsite flow }}{\text { head difference flow }}=\frac{0.204-0.157}{0.204}=23 \text { percent. }
$$

\section{Interaquifer Flow}

If a hydraulic connection exists between aquifers, interaquifer flow should go through the confining unit. However, no determinations of hydraulic connection between aquifers have been made. A hydraulic connection between aquifers cannot be assumed because of the areally extensive salt in the Paradox Formation within the confining unit (fig. 12), which often is assumed to indicate lack of hydraulic connection through the confining unit. Most of the following discussion is for areas where hydraulic connection exists between the aquifers.

Equivalent freshwater-head gradients, density differences, and possibly osmotic-pressure gradients affect interaquifer flow. In this section, only the effect of equivalent freshwater-head gradients and density differences is discussed. Their effects on flow are determined from equation 3 . For the confining unit, equivalent freshwater-head gradients and density were not known; consequently, approximations were necessary.

To approximate equivalent freshwater-head gradients in the confining unit, the difference in equivalent freshwater heads between the aquifers was calculated (fig. 12). Throughout most of the modeled area, higher equivalent freshwater heads occurred in the sandstone and red-bed aquifer than in the limestone and dolomite aquifer. The average measured equivalent freshwater head in the sandstone and red-bed aquifer was 5,355 $\mathrm{ft}$; the average measured equivalent freshwater head in the limestone and dolomite aquifer was 4,834 $\mathrm{ft}$. 
Only one area, denoted as "more certain equivalent freshwater-head difference" in figure 12, indicated upward flow through the confining bed (for the definition of "more certain" see subsection C, "Equivalent Freshwater-Head Differences Between Aquifers" in the "Supplemental Statistical Data" section at the back of this report). That area had a difference of $-1,125 \mathrm{ft}$ in equivalent freshwater head and was in Colorado. Nearby, other areas also had negative differences; these areas extended eastward into Colorado, but their differences were "less certain." Thus, a part of the recharge to the limestone and dolomite aquifer that occurred in Colorado could flow upward to the sandstone and red-bed aquifer.

Upward flow could exist in the south-central part of the modeled area a round Lake Powell (fig. 12). There, interpolated equivalent freshwater-head differences of almost $-600 \mathrm{ft}$ existed between aquifers. This was an area of possible upward flow from the limestone and dolomite aquifer; but a paucity of measurements in this area caused a larger error of interpolation there than in most other areas.

Another area of possible upward flow (fig. 12) through the confining unit was in the western part of the Paradox basin. Typical differences in equivalent freshwater head between the aquifers in the western Paradox basin were 200 to $300 \mathrm{ft}$. However, the effectiveness of these differences could be reversed by density differences.

Substantial density differences are largely the result of differences in dissolved-solids concentrations. The only area where large differences in dissolved-solids concentrations exist between the sandstone and red-bed aquifer and the limestone and dolomite aquifer is in the brine area (fig. 11). In that area, the average density of water in the confining unit was approximated by averaging the density of water in the sandstone and red-bed aquifer, and the density of water in the limestone and dolomite aquifer. Only in the brine area was this average substantially different than the reference density, $\rho_{o}$, the density of freshwater. The density ratio, $\Delta \rho / \rho_{0}$, was 0.079 , when the density of the brine was taken as $1.146 \mathrm{~g} / \mathrm{cm}^{3}$ and the density of freshwater was taken as $0.990 \mathrm{~g} / \mathrm{cm}^{3}$ as they were in the "Theory and Approximations" section. Because the density ratio was positive, the flow due to density differences in the confining unit was downward; equation 3 was used for determination of flow direction.

The effectiveness of the density differences in driving water through the confining unit can be expressed as a difference in equivalent freshwater heads. The equivalent freshwater-head difference that corresponds to the density ratio 0.079 is given by the formula:

$$
\begin{gathered}
\text { (equivalent freshwater-head difference) }=0.079 \\
\times \text { (thickness of the confining unit), }
\end{gathered}
$$

which is derived similarly to the inequality in equation 6 .

Where the confining unit is 3,000 ft thick, the density difference driving water downward corresponds to a difference in equivalent freshwater heads of $237 \mathrm{ft}$. In the eastern part of the Paradox basin, chemical osmotic-pressure gradients in the shale beds of the confining unit and presence of ground water of density larger than that of freshwater in the confining unit tended to drive water downward and probably nullified or reversed the effect of the differences between the aquifers in equivalent freshwater head. 


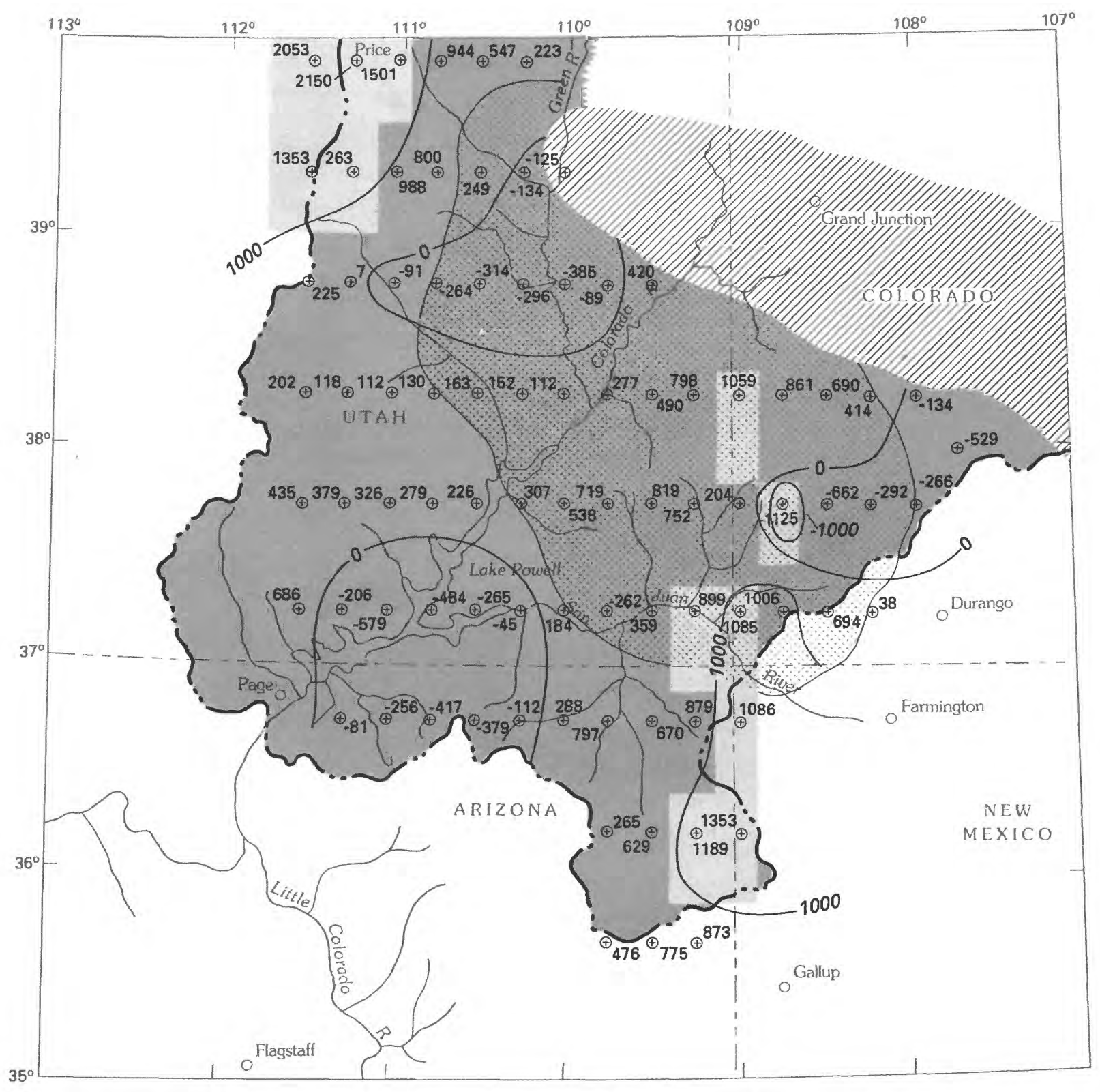

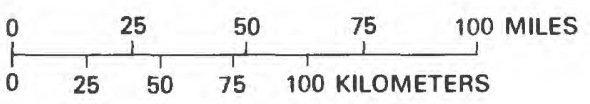

\section{EXPLANATION}

ROCKS OF PALEOZOIC AGE ABSENT (UNCOMPAHGRE UPLIFT)

PARADOX SALT

AREA OF MORE CERTAIN HEAD DIFFERENCE

AREA OF LESS CERTAIN HEAD DIFFERENCE
SOUTHERN UPPER COLORADO RIVER BASIN BOUNDARY

—1000 — LINE OF EQUAL DIFFERENCE IN EQUTVALENT FRESHWATER HEAD.-Interval 1,000 feet

$\oplus 873$ GRID POINT--Number is difference between interpolated equivalent freshwater head of the sandstone and red-bed aquifer and the limestone and dolomite aquifer. Negative differences indicate a potential for upward flow, and positive differences indicate a potential for downward flow

Figure 12.--Interpolated equivalent freshwater heads in the sandstone and red-bed aquifer minus interpolated equivalent freshwater heads in the limestone and dolomite aquifer at grid points. 
All facts about equivalent freshwater-head and density differences in the modeled area seem to support conclusions of widespread downward interaquifer flow. The following is a summary of those facts and conclusions:

- In most areas, larger equivalent freshwater heads occurred in the sandstone and red-bed aquifer than in the limestone and dolomite aquifer (fig. 12); this difference tends to drive ground water downward in those areas.

- In the brine area, density differences in the confining unit tended to drive water downward through the confining unit.

- Ground water in the limestone and dolomite aquifer generally contained much larger concentrations of dissolved solids than the ground water in the sandstone and red-bed aquifer (Lindner-Lunsford and others, 1989, figs. 13 and 15). Those concentrations might have been caused, in part, by general downward flow through the areally extensive salt of the Paradox Formation within the intervening confining unit.

\section{Osmotic-Pressure Gradients}

If beds acting as semipermeable membranes exist between the aquifers, osmotic-pressure gradients in the membranes can enhance, diminish, or reverse flow through the membrane that would be caused by the equivalent freshwater head and density differences between the ground water on both sides of the membrane. Osmotic-pressure gradients develop when a semipermeable membrane separates water having different chemical composition, different concentrations of dissolved solids, or temperatures. Everywhere in the modeled area the confining unit contains beds of shale, and shales can act as semipermeable membranes (Berry, 1969); thus, the possibility exists that the confining-unit shales are semipermeable membranes. Osmotic-pressure gradients have been studied in the laboratory and theoretically under conditions that approximate the ideal, but the transition from laboratory and theoretical results to the prediction of in-situ responses is difficult even if all the in-situ conditions are known. Laboratory results indicate that some of these non-Darcian responses can have substantial effects on leakage through semipermeable membranes (01sen, 1972).

\section{Chemical Osmosis}

Concentration differences always produce osmotic-pressure gradients that drive water from a small concentration to a large concentration; hence, for almost all parts of the modeled area, concentration differences tend to drive interaquifer flow downward. For sodium chloride solutions that are separated by an ideal semipermeable membrane and that have concentrations of 6 and 12 percent, a difference of osmotic-pressure heads in the ideal semipermeable membrane is 2,277 ft (Freeze and Cherry, 1979, p. 105). However, that difference, which is in the low hydraulic-conductivity shale, does not necessarily result in much flow compared to flow within the aquifer. Whether or not flow through the semipermeable membrane can cause equivalent freshwater-head changes in the aquifers on both sides depends on the rate at which equivalent freshwater-head changes can be dissipated by flow through the aquifers. 


\section{Electrical Osmosis}

Differences in chemical composition between the water on opposite sides of shale layers can cause leakage through the shale. If the different compositions have a tendency to combine, then a resulting electrical gradient develops across the shale. The electrical gradient induces leakage known as electrical osmosis. Although differences exist in chemical composition between the water on opposite sides of shale layers throughout the confining unit, not enough is known about these differences to determine the tendency of these opposing chemical compositions to combine and, subsequently, to determine the resulting electrical gradient that might develop across the shale.

\section{Thermal Osmosis}

Thermal osmosis causes flow through a semipermeable membrane from a hotwater reservoir to a cold-water reservoir (Dirksen, 1969; Srivastava and Avasthi, 1975). A temperature difference of $9^{\circ} \mathrm{F}$ between the two reserviours corresponds roughly to a difference in thermal-osmostic pressure head of $10 \mathrm{ft}$ (Srivastava and Avasthi, 1975). Other authors, for example, Mitchell (1976), indicate that thermal-osmotic effects are sma11 in saturated systems.

Because in southeastern Utah approximately a $1^{\circ} \mathrm{F}$ increase in temperature occurs for every $100 \mathrm{ft}$ of increasing depth, by applying laboratory results to shale layers in southeastern Utah, thermal-osmotic pressures could increase upward flow or decrease downward flow through a shale layer.

In the confining unit, the Molas Formation is the thickest shale layer; it has a maximum thickness of $150 \mathrm{ft}$, and perhaps, a maximum temperature difference between its upper and lower surface of 1 or $2^{\circ} \mathrm{F}$. Hence, a difference in thermal-osmotic pressure head of less than $10 \mathrm{ft}$ can be expected across the Molas Formation if it is a semipermeable membrane.

Bredehoeft (1965) estimated that under the best conditions, drill-stem tests in the Bighorn Basin had errors in measured pressure-head of $58 \mathrm{ft}$. If this estimate is accurate, then thermal-osmotic pressures in the system are very small relative to measurement error.

\section{Conclusions About Osmotic-Pressure Gradients}

Shale beds in the confining unit between the sandstone and red-bed aquifer and limestone and dolomite aquifer are beds wherein osmotic-pressure gradients could exist. These shale beds occur throughout most of the modeled area; therefore, osmotic-pressure gradients are possible throughout most of the modeled area.

Determination of osmotic-pressure gradients due to electrical fields requires more detailed knowledge than was available for the modeled area. Osmotic-pressure gradients due to temperature gradients are small and can be disregarded because of the larger uncertainty in measured equivalent freshwater heads.

Chemical-osmotic-pressure gradients are the only predictable, substantial osmotic-pressure gradients. The only area where chemical-osmotic-pressure gradients were likely to exist was in the shale beds above the brine area. Those pressure gradients would drive water downward. 


\section{Conclusions About the Direction of Interaquifer Flow}

Upward interaquifer flow from the limestone and dolomite aquifer to the sandstone red-bed aquifer seemed likely in only two areas. One area was in Colorado and one area was in the south-central part of the modeled area where the Colorado River enters Arizona. These areas are defined in figure 12 by negative interaquifer differences in equivalent freshwater head.

Another area of negative interaquifer differences in equivalent freshwater head was in the western part of the Paradox basin. In this area, chemical-osmotic-pressure gradients in the shale beds of the confining unit and presence of ground water of density larger than that of fresh water in the confining unit tended to drive water downward and probably nullified or reversed the effect of the differences in equivalent freshwater head between the aquifers.

\section{Magnitude of Interaquifer Flow}

Besides the direction of interaquifer flow, the magnitude of interaquifer flow relative to the magnitude of intraaquifer flow is an important characteristic of the ground-water system. However, because considerable uncertainty existed about the pressure gradients in the confining unit because of osmotic effects and the average vertical hydraulic conductivity of the confining unit, the relative magnitudes of interaquifer flow and intra-aquifer flow could not be estimated.

To determine whether interaquifer flow was needed for a consistent explanation of the hydrological data, a flow model of each aquifer that did not permit interaquifer flow was used to simulate equivalent freshwater heads. If these flow models simulated equivalent freshwater heads that closely matched measured equivalent freshwater heads, then the assumptions of the models, including the zero interaquifer flow assumption, would have credibility.

\section{BOUNDARY INTEGRAL-EQUATION METHOD FOR SIMULATION OF GROUND-WATER FLOW}

Three numerical methods can be used to approximate solutions to the ground-water-flow equation: two domain methods (finite differences and finite elements) and one nondomain method (the boundary-element method or boundany integral-equation method). To use domain methods, the aquifer must be partitioned into squares, rectangles, triangles, or other shapes; to use the boundary integral-equation method, only the boundary of the aquifer needs to be partitioned. From this difference, some of the advantages and disadvantages of the boundary integral-equation method follow:

Advantages :

- Fewer data are required; a two-dimensional problem becomes a one-dimensional problem.

- Fewer equations need to be solved.

- The numerical accuracy generally is greater; see Brebbia (1978, p. 80-81) for a comparison.

- Numerical accuracy can be estimated easily. 
Disadvantages :

- For complicated spatial variations in aquifer parameters, the method becomes similar to a domain method.

- Transient problems are not natural to the boundary integral-equation method.

When domain methods are applied to regional-aquifer problems, the tendency is to increase the size of the domains to decrease input and output requirements. Large domains usually result in a less accurate approximate solution than small domains. The accuracy cannot be estimated without considerably more work than that done in obtaining the approximate solution; for example, see Weiss (1986).

For this study, the principal advantages of the boundary integralequation method are: The accuracy of calculation provided for a regional model, and (2) the ease with which many quick simulation experiments can be done. The accuracy and ease require some simplifying assumptions that seem valid:

(1) Ground water is the same density everywhere. That assumption should be valid for the model of the sandstone and red-bed aquifer because dissolvedsolids concentrations vary from 1 to $10 \mathrm{~g} / \mathrm{L}$, which probably causes only small density variations. For the model of the limestone and dolomite aquifer in the brine area, dissolved-solids concentrations can be $374 \mathrm{~g} / \mathrm{L}$. The brine area is not part of that model.

(2) The ground-water system is in steady state. Because of the small rate of ground-water withdrawal from aquifers throughout the modeled areas, that assumption seems valid.

(3) The aquifer is represented in simulations as two dimensional and flat. In spite of large changes in aquifer altitude, this assumption yields accurate simulations (Weiss, 1985).

(4) The equivalent freshwater head and the component of the equivalent freshwater-head gradient normal to the boundary are linear functions along each boundary element. That assumption is a reasonable, common interpolation.

If the above assumptions are accurate, the following simplifying approximations for both aquifers probably can be tested by simulation:

(1) The aquifers have the same transmissivity everywhere. Although the permeability measurements indicate no regional trends or local autocorrelations in transmissivity (table 2), this is an approximation to be tested further by simulation.

(2) No interaquifer flow occurs.

The outcome of the simulation test depends on the uncertainty in the values of measurements to which the values of the simulations are compared. When uncertainty can be decreased, simulations might provide better tests of those approximations. 
The boundary-element code, called GM8, used for all simulations in this chapter, is described and documented in Liggett and Liu (1983, p. 214-222); the complete theory and many applications of the boundary integral-equation method are detailed in that reference.

For GM8, a boundary element is a straight line having a node at each end. A concatenation of boundary elements form the boundary of the modeled area and separate the inside of the modeled area from the outside. Use of GM8 requires input values of equivalent freshwater head or its normal derivative (the component of the gradient of equivalent freshwater head normal to the boundary element) at each node. If one is specified, the other is calculated by assuming both to vary linearly along boundary elements. By using the result of that calculation, equivalent freshwater head at arbitrary internal (nonboundary) points can be calculated.

To check simulation adequacy, calculated values of equivalent freshwater head at internal points were compared to measured values. Then calculations were done for internal grid points to determine details of the simulated flow pattern in the modeled area.

The calculations at internal points use the results of the calculations at the boundaries of the modeled area; the accuracy at internal points depends on the accuracy at the boundaries. But the accuracy of calculated boundary values depends on the assumption that the calculated values vary linearly between nodes. That assumption usually is not consistent with the assumption that the input values vary linearly between nodes. To improve the calculation, each boundary element is divided in half, producing two boundary elements where there was one, enabling a new calculation that has two independent linear variations for the calculated values in place of one along each old boundary element. Those two linear variations produce a better approximation for the calculated boundary values than the one linear variation. At the newly created node in the center of each old boundary element, a linear interpolation of the old input boundary values was input to maintain the old input boundary values.

A new simulation using twice the number of boundary elements recalculated internal equivalent freshwater heads; the mean absolute difference of internal equivalent freshwater heads between the two simulations was the estimated error in the old simulation. It is listed in the last line in table 4 as the "Estimated error in simulation calculation." 
Table 4.--Boundary values and calibration statistics for the model of the sandstone and red-bed aquifer

(modified from Weiss, 1987)

[A11 equivalent freshwater heads are measured values except at nodes where derivatives normal to the boundary are zero. All normal derivatives are calculated except at nodes where they are zero. A negative normal derivative indicates flow out of the model boundary.]

Input and output at boundary nodes

\begin{tabular}{|c|c|c|c|}
\hline $\begin{array}{c}\text { Equivalent } \\
\text { freshwater } \\
\text { head } \\
\text { (feet) }\end{array}$ & $\begin{array}{l}\text { Normal derivative } \\
\text { (feet per mile) }\end{array}$ & $\begin{array}{c}\text { Equivalent } \\
\text { freshwater } \\
\text { head } \\
\text { (feet) }\end{array}$ & $\begin{array}{l}\text { Normal derivative } \\
\text { (feet per mile) }\end{array}$ \\
\hline $\begin{array}{l}7,330 \\
5,130 \\
4,920 \\
4,920 \\
8,220\end{array}$ & $\begin{array}{r}255.6 \\
-51.2 \\
23.0 \\
-49.8 \\
76.5\end{array}$ & $\begin{array}{l}3,280 \\
3,700 \\
4,120 \\
4,120 \\
3,700\end{array}$ & $\begin{array}{r}-28.7 \\
-24.3 \\
-97.8 \\
-30.7 \\
-.2\end{array}$ \\
\hline $\begin{array}{l}5,875 \\
5,050 \\
4,101 \\
4,000 \\
3,800\end{array}$ & $\begin{array}{r}.0 \\
.0 \\
.0 \\
9.0 \\
-1.9\end{array}$ & $\begin{array}{l}3,490 \\
3,700 \\
3,800 \\
4,000 \\
4,573\end{array}$ & $\begin{array}{r}-1.0 \\
-15.7 \\
-51.8 \\
-41.3 \\
.0\end{array}$ \\
\hline $\begin{array}{l}3,900 \\
4,000 \\
4,000 \\
3,900 \\
3,800\end{array}$ & $\begin{array}{r}-.4 \\
-52.3 \\
-91.8 \\
-3.7 \\
.2\end{array}$ & $\begin{array}{l}5,975 \\
7,310 \\
7,960 \\
7,000 \\
5,170\end{array}$ & $\begin{array}{r}.0 \\
.0 \\
70.0 \\
37.0 \\
-18.0\end{array}$ \\
\hline $\begin{array}{l}3,750 \\
3,700 \\
3,900 \\
3,900 \\
3,700\end{array}$ & $\begin{array}{r}-.3 \\
2.1 \\
-.3 \\
-46.5 \\
-3.3\end{array}$ & $\begin{array}{l}7,430 \\
7,070 \\
6,350 \\
5,325 \\
4,300\end{array}$ & $\begin{array}{r}94.1 \\
29.1 \\
5.3 \\
11.9 \\
20.3\end{array}$ \\
\hline $\begin{array}{l}3,490 \\
3,280\end{array}$ & $\begin{array}{r}-33.8 \\
-324.8\end{array}$ & 3,000 & -117.1 \\
\hline
\end{tabular}

Statistics for 62 measured equivalent freshwater heads at internal points

Coefficient of determination-

Mean residual (measured minus simulated)

Mean absolute residual-

Root-mean-square residual-a

Largest residual

Estimated error in simulation calculation-
0.70

-128 feet

496 feet

628 feet

1,710 feet

48 feet 


\section{Model of the Sandstone and Red-bed Aguifer}

Many different simulations were attempted that only allowed discharge from the sandstone and red-bed aquifer into the Marble Canyon in Arizona. However, it was impossible to achieve a reasonable match to measured internal equivalent freshwater heads by varying the location and equivalent freshwaterhead values associated with the Marble Canyon discharge area. "Even after assuming a no-flow boundary along the Uncompahgre uplift, the match to internal equivalent freshwater heads was poor, although much improved. After many simulations, some with unreasonably small equivalent freshwater heads at the Marble Canyon, the attempt to match internal equivalent freshwater heads without discharge in the middle of the modeled area was abandoned.

The best match to internal equivalent freshwater heads required a configuration of boundary elements that allowed discharge along the Colorado River and its tributaries in the center of the modeled area; the configuration was based on the location of Paleozoic rock outcrops in stream channels shown in figure 13. The altitude of the streams is given at selected points along the channels. The channel locations and stream altitudes were used for the location and equivalent freshwater heads at the nodes of boundary elements shown in the middle of figure 14 .

The simulation that used the boundary integral-equation configuration shown in figure 14 achieved the best match to the internal equivalent freshwater heads. A large quantity of inflow to the aquifer occurs in the southwestern part of the model boundary; most of the inflow is discharged into the nearby Colorado River channel and the Marble Canyon. Other large inflows occur in the northwestern and northeastern areas of the modeled area.

The channel representing Dark Canyon is not shown in figure 14 because sensitivity analysis indicates Dark Canyon is part of a local flow system, which is poorly understood. The sensitivity to inclusion of the Dark Canyon outcrop area is discussed in the next section.

Initial simplifying approximations were part of the best simulation of the sandstone and red-bed aquifer and seem to be reasonable approximations. They are:

(1) The aquifer has the same transmissivity everywhere. Transmissivity was not an input to the simulation; consequently the transmissivity was not estimated by the simulation. An estimate of transmissivity should be based on the thickness and the geometric mean value of permeability in table 2: 4 millidarcies per centipoise.

(2) No interaquifer flow occurs for the sandstone and red-bed aquifer.

(3) There is a no-flow boundary along the Uncompahgre uplift.

(4) Discharge at stream channels in the center of the modeled area is controlled by the altitude of the stream, except in Dark Canyon, which probably is a discharge area for local flow.

(5) Discharge into the Marble Canyon is controlled by the altitudes of the Paleozoic rock outcrops. 

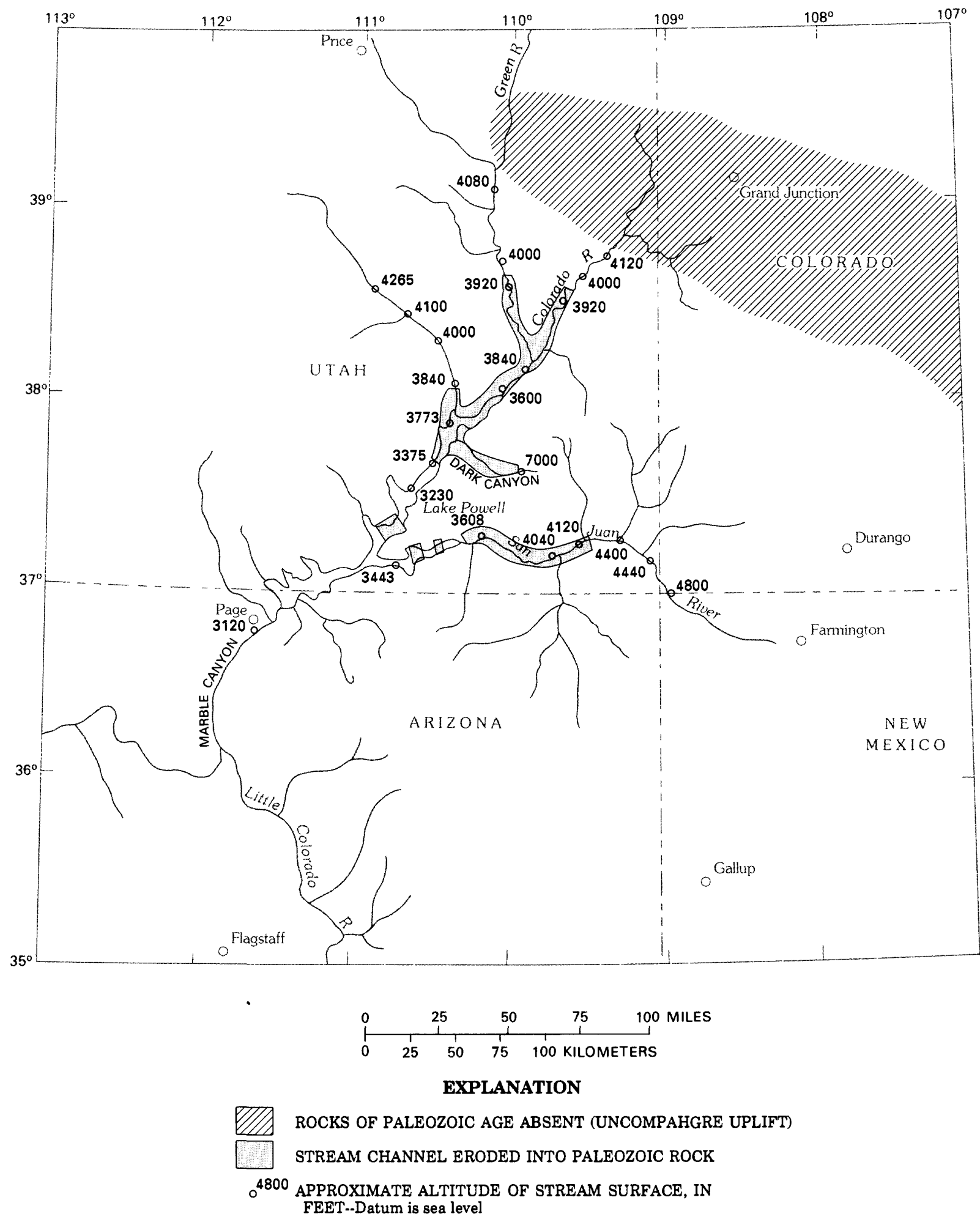

Figure 13.--Stream-surface altitudes and areas of contact between stream channels and the sandstone and red-bed aquifer (modified from Weiss, 1987). 

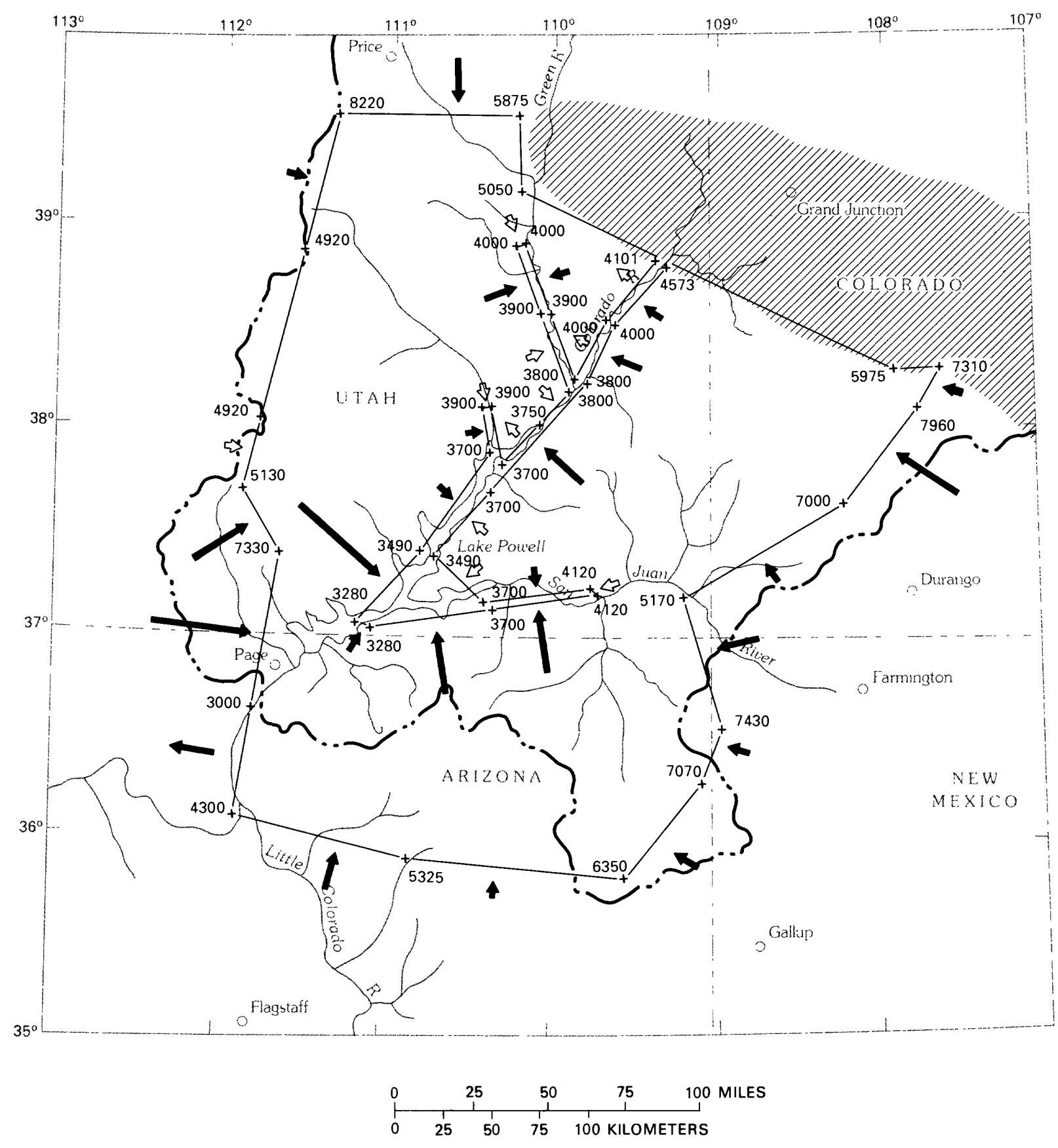

EXPLANATION

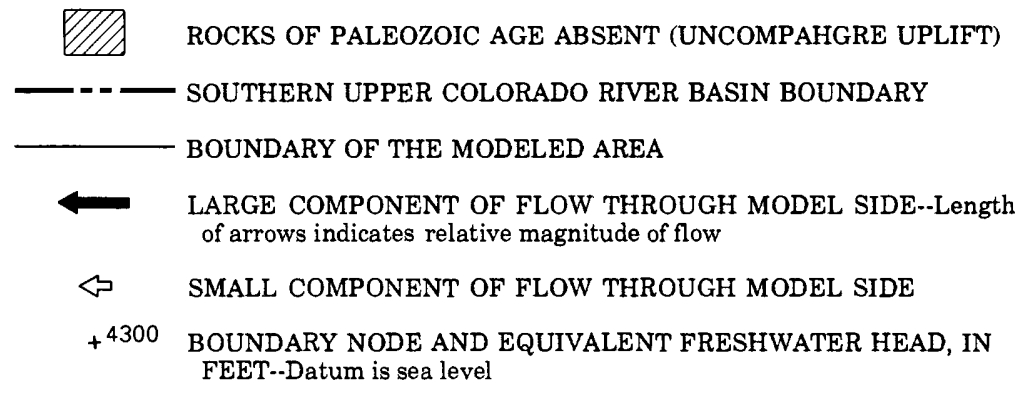

Figure 14.--Model of the sandstone and red-bed aquifer using the boundary integral-equation method (modified from Weiss, 1987). 
The model of the sandstone and red-bed aquifer was developed without adjusting any parameters to fit the internal measured equivalent freshwater heads. All parameters used in the model were the result of measurements and assumptions. Primarily, transmissivity was not adjusted. However, trial simulations were used to decide the need for internal recharge and discharge areas. Need was decided on the basis of hydrologic judgment and on the basis of the agreement between simulated and measured equivalent freshwater heads.

Statistics for each simulation were compared to determine the best simulation. The statistics for the best simulation are listed in table 4 . The coefficient of determination in table 4 indicates that 70 percent of the variation in measured equivalent freshwater-heads is accounted for by the best simulation. It is an adequate simulation, as is explained in subsection $B$, "Process Error and Model Error" in the "Supplemental Statistical Data" section at the back of this report.

The equivalent freshwater heads and their normal derivatives are listed in table 4 for each node that is shown in figure 14. The contours of simulated equivalent freshwater heads are shown in figure 15 . The contours of simulated equivalent freshwater head are similar to the contours of interpolated measured equivalent freshwater head in figure 5 . Both sets of contours indicate that ground water generally flows from the eastern and the western boundaries of the modeled area toward the Colorado River. Near the northern boundary of the modeled area and at the Green River, a small component of ground water flows south.

The differences between measured equivalent freshwater heads and simulated equivalent freshwater heads--the residuals of model simulation--are shown in figure 16. The largest residuals are in the southeast corner of Utah, west of, and south of the Uncompahgre uplift where residuals are more than $400 \mathrm{ft}$. A test of the residuals' normality proved them to be normally distributed at a 95-percent confidence level. The distribution of residuals along the west-east direction and along the south-north direction are shown in figure 17. The distribution along the west-east direction seems fairly uniform, but the residuals along the south-north direction seem to increase toward the north.

Sensitivity of the Model of the Sandstone and Red-bed Aquifer

Every assumption, boundary condition, and parameter used in a model has some uncertainty. Simulations usually are more sensitive to changes in some of these than others. By identifying the assumption, boundary condition, or parameter of greatest sensitivity, additional measurements that decrease these uncertainties are most effective in decreasing simulation uncertainty.

The 8,220-ft equivalent freshwater head at the northwestern corner of the boundary of the model is one of the uncertain equivalent freshwater heads discussed in the section "Process Error." If an equivalent freshwater head $1,000 \mathrm{ft}$ lower is substituted for the 8,220-ft equivalent freshwater head, then the calibration statistics are not significantly changed because only three nearby equivalent freshwater-head measurements exist, and they are about $50 \mathrm{mi}$ away. The model is insensitive to the uncertainty in the $8,220-\mathrm{ft}$ equivalent fresh-water head at the northwestern corner of the model boundary. 

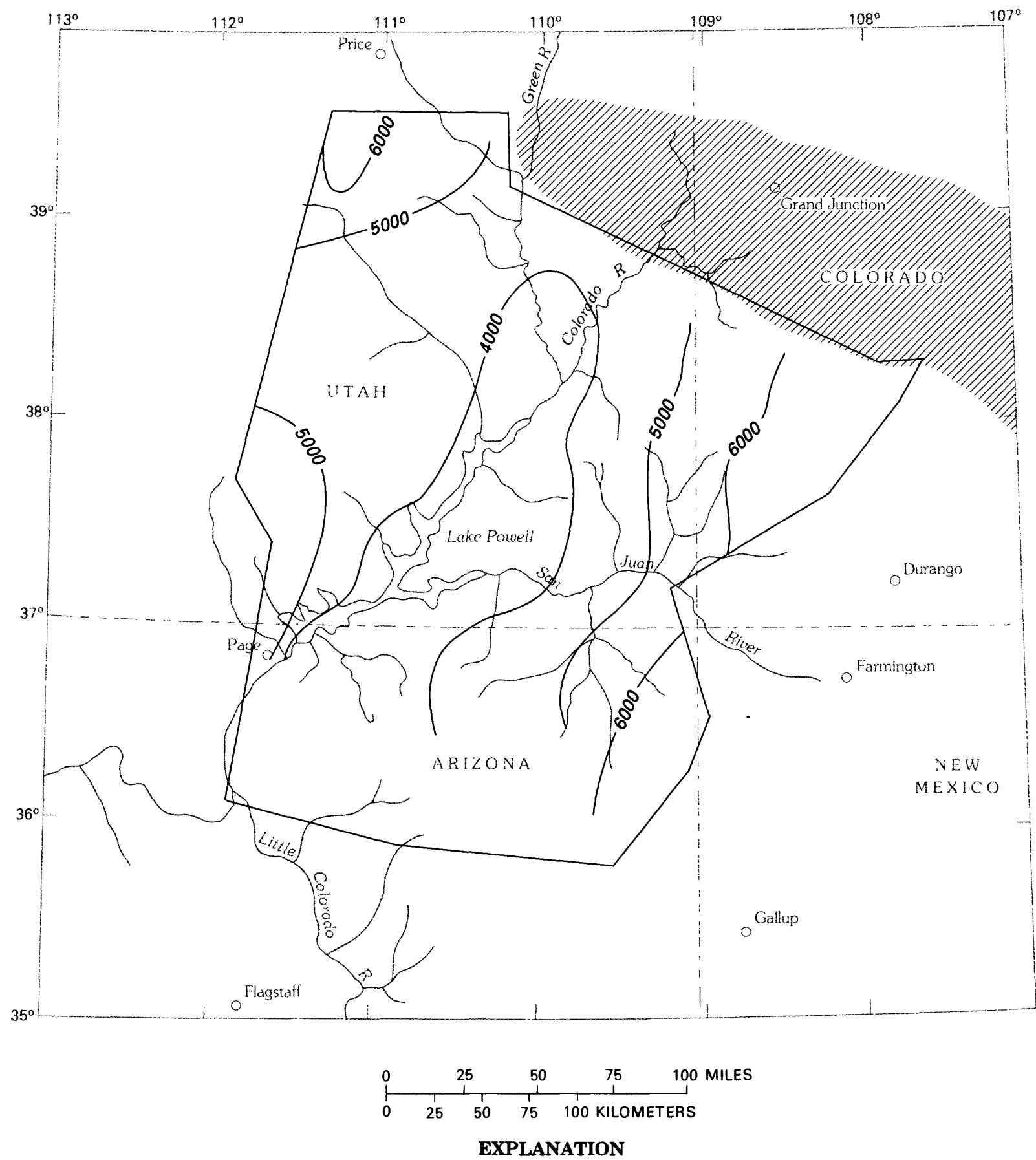

\footnotetext{
ROCKS OF PALEOZOIC AGE ABSENT (UNCOMPAHGRE UPLIFT) BOUNDARY OF THE MODELED AREA

— 5000 - LINE OF EQUAL EQUIVALENT FRESHWATER HEAD--Interval 1,000 feet
}

Figure 15.--Contours of simulated equivalent freshwater head for the sandstone and red-bed aquifer. 

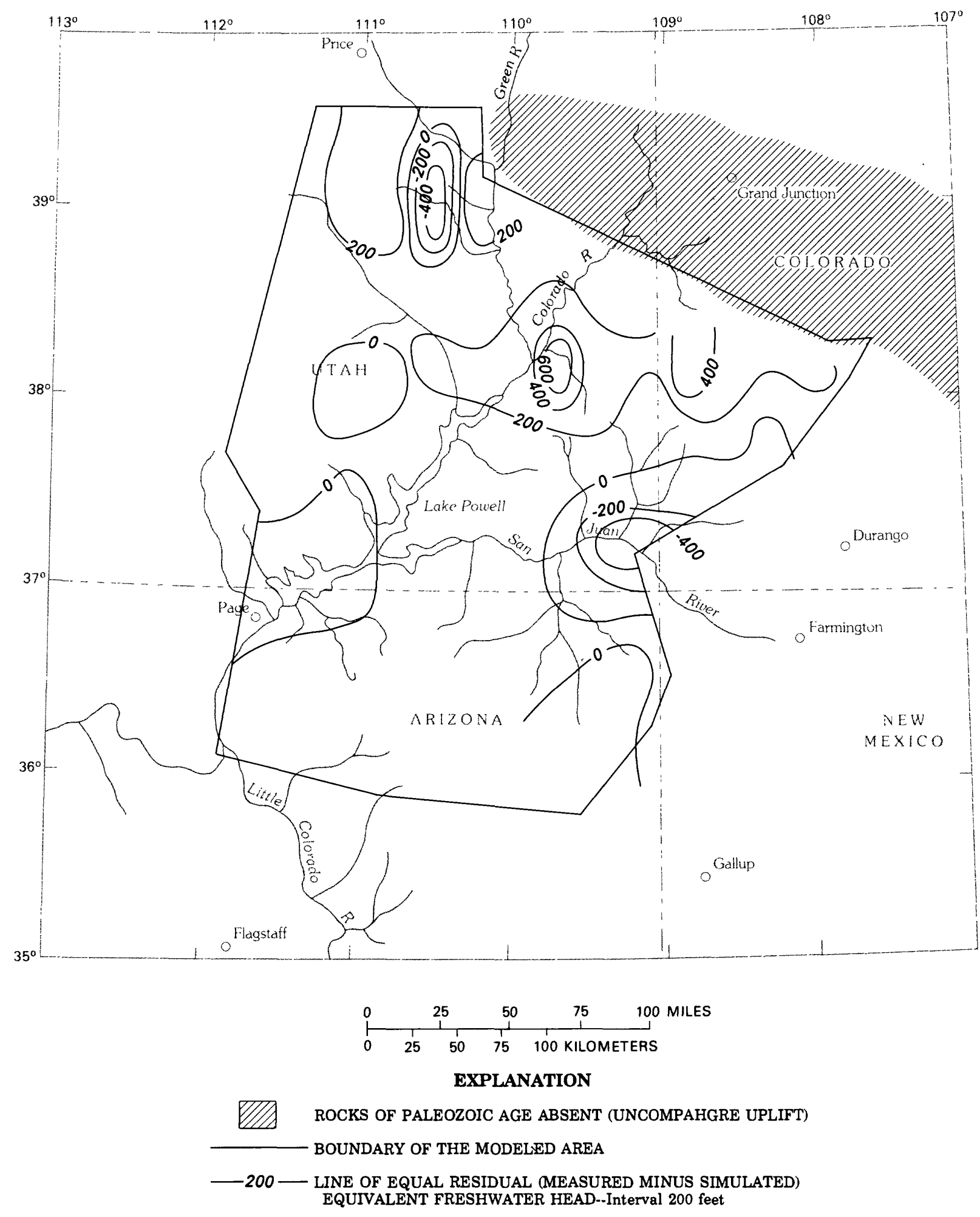

Figure 16.--Contours of residuals from the model of the sandstone and red-bed aquifer. 

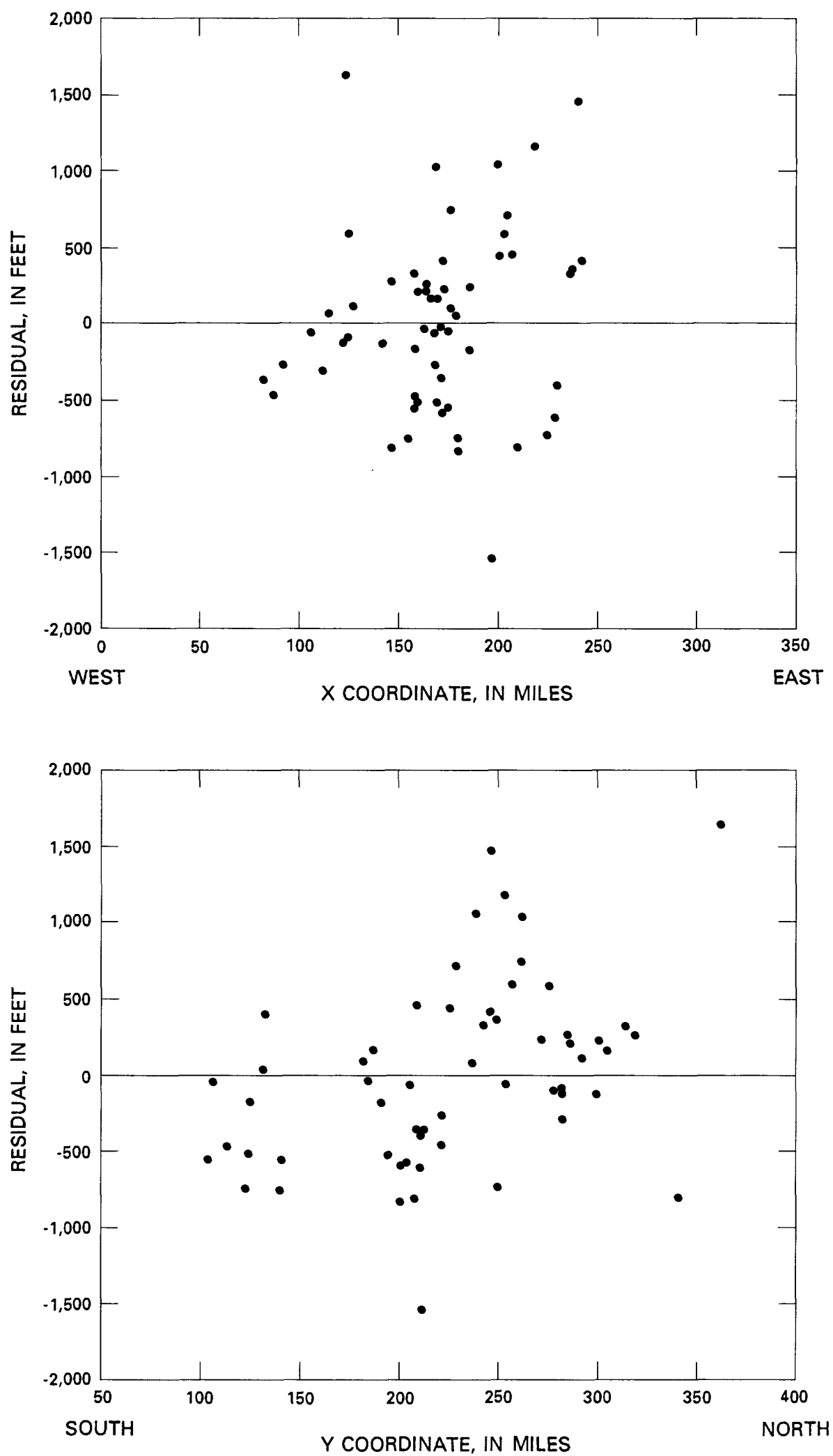

Figure 17.--Equivalent freshwater-head residuals from the model of the sandstone and red-bed aquifer. 
When the discharge from the Paleozoic outcrops in Marble Canyon was decreased to zero, that is, when the normal derivatives of $20.3 \mathrm{ft} / \mathrm{mi}$ and $-117.1 \mathrm{ft} / \mathrm{mi}$ in table 4 were set to zero in the input of GM8, then only very minor changes occurred in the simulated internal equivalent freshwater heads. Compared to the discharge in stream channels upstream, discharge to Marble Canyon is an insubstantial discharge for regional, but not local flow.

Large changes in calibration statistics were simulated when substantial recharge at the southern edge of the Uncompahgre uplift was included.

When Dark Canyon stream channel and stream-altitude value (shown in fig. 13) were added as a recharge boundary to the internal-boundary elements shown in figure 14, simulated internal equivalent freshwater heads increased significantly, and calibration statistics decreased to unacceptable levels. The average equivalent freshwater-head difference increased by almost $200 \mathrm{ft}$, indicating that the large mound in the potentiometric surface, shown in figure 5 by the contours from Thackston and others (1981), does not indicate flow entering the regional-flow system. That large mound in the potentiometric surface probably is isolated from the regional-flow system and is discharging locally. The relation of the spring-defined mound to regional flow was poorly understood (Dunbar and Thackston, 1985, p. 73).

The sensitivity of model results to the value of the equivalent freshwater head at the nodes near the confluence of the San Juan and Colorado Rivers was tested by changing the nodal value from $3,280 \mathrm{ft}$ to $3,500 \mathrm{ft}$. The mean absolute residual changed from $496 \mathrm{ft}$ to $501 \mathrm{ft}$, and some other statistics had similar small changes.

Sensitivities of the simulation of the sandstone and red-bed aquifer were investigated. The only substantial change to the calibration statistics occurred when the addition of recharge near Dark Canyon and the southern edge of the Uncompahgre uplift was included, which indicated that both of those recharges were unlikely onsite. Therefore, measurements of the recharge near Dark Canyon could decrease simulation uncertainty.

\section{Model of the Limestone and Dolomite Aquifer}

Because the GM8 code simulates only ground-water flow that has a constant density and because very little flow is likely out of the brine area (see section entitled "Brine Flow in the Limestone and Dolomite Aquifer"), the brine area was eliminated from the model of the limestone and dolomite aquifer.

The best match to internal equivalent freshwater heads required a boundary-element configuration of discharging stream channels near the center of the modeled area. The configuration of boundary elements follows the Pennsy1vanian rock outcrops in canyons shown in figure 4. The boundary-element configuration does not include the Pennsylvanian rock outcrop in Dark Canyon. Approximations in the simulation of the limestone and dolomite aquifer that seem to be reasonable are:

- The boundary of the brine area is a no-flow boundary.

- Discharge at Pennsylvanian rock outcrops in stream channels in the center of the modeled area is controlled by the altitude of the stream.

- Discharge into the Marble Canyon is controlled by the altitudes of the Paleozoic rock outcrops. 
The limestone and dolomite aquifer also was developed without adjusting any parameters. All parameters used in the model were the result of measurements and assumptions; no adjustment was made to fit the internal measured equivalent freshwater heads.

The statistics for the simulated and measured internal equivalent freshwater heads also are listed in table 5. All the statistics are worse than the statistics for the sandstone and red-bed aquifer. The mean absolute residual is $637 \mathrm{ft}$, which is more than the $569 \mathrm{ft}$ of random component in the equivalent freshwater heads in the limestone and dolomite aquifer; thus, the limestone and dolomite aquifer does not account well for the interpolated equivalent freshwater-head distribution. Consequently, the model is unsatisfactory, and one or more of its assumptions could be a poor approximation.

\section{Table 5.--Calibration statistics for the model of the limestone and dolomite aquifer}

Statistics for 108 measured equivalent freshwater heads at internal points

Coefficient of determination-

Mean residual (measured minus simulated)

Mean absolute residual-_.

Root-mean-square residual-_-

Largest residual-a-

0.49

-282 feet

637 feet

821 feet

2,375 feet

The mean absolute residuals listed in tables 4 and 5 indicate that both simulations had larger average simulated equivalent freshwater heads than average measured equivalent freshwater heads, the difference being more than twice as large for the aquifer flow simulation of the limestone and dolomite aquifer as for the flow simulation of the sandstone and red-bed aquifer. When stream altitudes in the models were decreased, discharge to stream channels increased and simulated heads decreased; however, there is no other justification for decreasing stream altitudes.

The principal problem in simulating accurate flow in the limestone and dolomite aquifer was simulating equivalent freshwater heads that were small enough to match measured equivalent freshwater heads. To do this, additional discharge was needed. Discharge occurred primarily in the stream channels at the center of the modeled area. This discharge probably was larger in the model than it should have been because in the model it flowed directly from the aquifer to the stream channel instead of flowing from the aquifer through the confining unit to the stream channel, as it would have done onsite, if onsite discharge to the stream channel occurs. Consequently, discharge to the stream channels seems to be maximized in the simulation of the limestone and dolomite aquifer; and onsite discharge from the limestone and dolomite aquifer probably occurs in and near the stream channels instead of only in the stream channels of the model. However, differences in equivalent freshwater head between the aquifers generally do not support this hypothesis.

Another series of simulations was done. These simulations were given zones of transmissivity: two zones of small transmissivity and one zone of large transmissivity between the two zones of small transmissivity. For the variable-transmissivity model, computer code GM4 was used (obtained from Cornel1 University and unpublished) because GM8 can simulate only uniform transmissivities. None of these variable-transmissivity simulations produced a reasonable match to the internal equivalent freshwater heads. 


\section{Does Variable-Density Flow Need to be Simulated?}

Because the simulation of flow in the limestone and dolomite aquifer was inadequate and generally had poor calibration statistics (table 5), the question arises: Does variable-density flow need to be simulated?

Approximate steady-state, variable-density flow can be simulated by using constant-density simulations if sinks and sources of ground water are appropriately distributed within the modeled area, but the sinks and sources must always contribute a zero net flow to the aquifer (Weiss, 1982, p. 16). As a result, if such an approximate variable-density simulation were used, and if it had parameters identical to the constant density simulation, the simulation would have a similar mean residual because no net discharge would be included to decrease the mean residual. Consequently for the limestone dolomite aquifer, data indicating additional discharge in the center of the modeled area or indicating upward interaquifer flow, perhaps in Colorado near the Utah-Colorado border, seem a more likely key to an improved understanding of the flow than does simulating variable-density flow.

\section{SUMMARY AND CONCLUSIONS}

In this report, the definitions of aquifers and confining units are similar to those used in previous reports. Both modeled aquifers and the intervening confining unit extend over the entire modeled area. The sandstone and red-bed aquifer consists of Permian rocks plus the Honaker Trail Formation, which is of Pennsylvanian age. The other rocks of Pennsylvanian age are defined as a confining unit. Beneath the confining unit is the limestone and dolomite aquifer that consists of Mississippian and Devonian rocks.

Permeability values were lognormally distributed for each aquifer, and no regional trend in values was indicated for the two aquifers. The permeability values for the sandstone and red-bed aquifer were too few to test for local autocorrelations, but the permeability values for the limestone and dolomite aquifer had no local autocorrelations larger than 15 miles. The geometric mean of permeability measurements for the sandstone and red-bed aquifer was 4 millidarcies per centipoise, and the geometric mean of permeability measurements for the limestone and dolomite aquifer was 424 millidarcies per centipoise. A large probability exists that the mean permeability of the sandstone and red-bed aquifer is one-hundredth of the mean permeability of the limestone and dolomite aquifer.

In both aquifers, regional trends and local autocorrelations in equivalent freshwater-head values exist. Using the local autocorrelations based on empirical semivariograms, the data were interpolated to a grid; an error of interpolation is given at each grid point: about 600 feet, except near the boundaries where it is as large as 1,000 $\mathrm{ft}$.

Equivalent freshwater-head contours based on geostatistical interpolations of equivalent freshwater heads indicated general ground-water movement from the boundaries of the modeled area to the center of both aquifers. Contours for both aquifers indicate a primary discharge area near the center of the modeled area, but only the sandstone and red-bed aquifer outcrops there. At the center of the modeled area, the mode of discharge for the limestone and dolomite aquifer might be upward through the confining unit, but differences in equivalent freshwater head between the aquifers generally do not support this hypothesis. 
Equivalent freshwater-head differences between the aquifers indicate predominantly downward flow. Semipermeable membranes could exist in the confining unit between the aquifers because of the presence of many shale layers. If semipermeable membranes are in the confining unit, interaquifer flow is not only determined by interaquifer equivalent freshwater-head and density differences but also by osmotic-pressure gradients in the semipermeable membranes. Throughout most of the modeled area, osmotic-pressure gradients in semipermeable membranes caused by differences in concentrations of dissolved solids on the sides of the shale would tend to move water downward. Differences in dissolved-solids concentrations could produce large osmotic-pressure gradients in the shale, but differences in temperature produce very small osmotic-pressure gradients.

The ratio of interaquifer flow to areal flow through the aquifers cannot be estimated reliably because the vertical hydraulic conductivity of the confining unit was unknown. However, simulations indicate that interaquifer flow is not necessary for an adequate model of the sandstone and red-bed aquifer. Consequently, interaquifer flow probably is small compared to areal flow for the sandstone and red-bed aquifer.

A brine that has concentrations of dissolved solids as large as $374 \mathrm{~g} / \mathrm{L}$ is present in the limestone and dolomite aquifer in the Paradox basin area. The interpolated equivalent freshwater heads at grid points in the modeled area and in the brine area of the limestone and dolomite aquifer defined 11 flow paths that have an equivalent freshwater-head difference driving water out of the brine area. However, the gravitational force pulling the more dense brine downslope into the Paradox basin prevents the brine from flowing out of the basin along most flow paths.

Flow between the sandstone and red-bed aquifer and the limestone and dolomite aquifer was not simulated. The adequacy of both flow models was judged by comparing root-mean-square error in simulated equivalent freshwater heads to the root-mean-square error in measured equivalent freshwater heads. The model of the sandstone and red-bed aquifer was adequate because the root-mean-square model error in simulated equivalent freshwater heads was approximately equal to the root-mean-square measurement error in measured equivalent freshwater heads. That approximate equality indicated that equivalent freshwater heads simulated by the model could be as accurate in predicting true equivalent freshwater-head values as would additional drillstem-test measurements of equivalent freshwater head. To simulate equivalent freshwater heads that were small enough on average to match measured equivalent freshwater heads, additional discharge was needed. Simulating variabledensity flow will not fulfill this need; therefore it should not be a primary concern.

The model of the limestone and dolomite aquifer was not adequate. The model of regional flow for the sandstone and red-bed aquifer had no adjustable parameters; transmissivity was not an input to the adequate simulation; consequently, the transmissivity was not estimated by simulation. An estimate of transmissivity needs to be based on the thickness of the aquifer and the geometric mean value of permeability, which is 4 millidarcies per centipoise. 
In both flow models, discharge occurred primarily in the stream channels at the center of the modeled area. However, discharge from the model of the limestone and dolomite aquifer was not large enough for an adequate simulation even though the discharge to the stream channels was apparently maximized.

\section{REFERENCES CITED}

Baars, D.L., 1983, The Colorado Plateau a geologic history: Albuquerque, University of New Mexico Press, p. 279.

Bair, E.S., O'Donne11, T.P., and Picking, L.W., 1985, Potentiometric mapping from incomplete drill stem test data--Palo Duro Basin area, Texas and New Mexico: Ground Water, v. 23, no. 2, p. 198-211.

Berry, F.A.F., 1969, Relative factors influencing membrane filtration effects in geologic environments: Chemical Geology, v. 4, no. 1-2, p. 295-301.

Brebbia, C.A., 1978, The boundary element method for engineers: New York, John Wiley, $189 \mathrm{p}$.

Bredehoeft, J.D., 1965, The drill stem test--The petroleum industry's deepwell pumping test: Groundwater, v. 3, no. 3, p. 31-36.

Clark, Isobel, 1979, Practical geostatistics: London Applied Science Publishers, 129 p.

David, Michel, 1977, Geostatistical ore reserve estimation: Amsterdam, Elsevier, $364 \mathrm{p}$.

Dirksen, C., 1969, Thermo-osmosis through compacted saturated clay membranes: Soil Science Society of America, Proceedings, v. 33, no. 6, p. 821-826.

Dunbar, D.B., and Thackston, J.W., 1985, Status Report: Numberical modeling of ground-water flow in the Paleozoic formations, western Paradox basin, Utah: Columbus, Ohio, Battelle Memorial Institute, Office of Nuclear Waste Isolation, no. BMI/ONWI-571, 85 p.

Freeze, R.A., and Cherry, J.A., 1979, Groundwater: Englewood Cliffs, N.J., Prentice-Hall, Inc., $604 \mathrm{p}$.

Hanshaw, B.B., and Hill, G.A., 1969, Geochemistry and hydrodynamics of the Paradox Basin regiona, Utah, Colorado, and New Mexico: Chemical Geology, v. 4, no. 1-2, p. 263-294.

Henley, Stephen, 1981, Nonparametric geostatistics: London, Applied Science ublishers, $145 \mathrm{p}$.

Horner, D.R., 1952, Pressure buildup in wells, in World Petroleum Congress (3d), Proceedings, The Hague, Netherlands, 1951: Sec. II, p. 503-521.

Journel, A.G., and Huijbregts, C.J., 1978, Mining geostatistics: New York, Academic Press, 600 p.

Kafritaas, John, and Bras, R.L., 1981, The practice of kriging: Cambridge, Massachusetts Institute of Technology, Ralph M. Parsons Laboratory report no. $263,63 \mathrm{p}$.

Karlinger, M.R., and Skrivan, J.A., 1980, Kriging analysis of mean annual precipitation, Powder River Basin, Montana and Wyoming: U.S. Geological Survey Water-Resources Investigatoins 80-50, $25 \mathrm{p}$.

Liggett, J.A., and Liu, P.L-F., 1983, The boundary integral equation method for porous media: London, George Allen and Unwin, 255 p. 
Lindner-lunsford, J.B., Kimba11, B.A., Chafin, D.T., and Bryant, C.G., 1989, Hydrogeology of aquifers of Paleozoic age, Upper Colorado River Basin, excluding the San Juan Basin, in Colorado, Utah, Wyoming, and Arizona: U.S. Geological Survey Hydrologic Atlas HA-702, scale 1:2,500,000, 2 sheets.

Mitche11, J.K., 1976, Fundamentals of soil behavior: New York, John Wiley, p. 341 .

Olsen, H.W., 1972, Liquid movement through kaolinite under hydraulic, electric, and osmotic gradients: The American Association of Petroleum Geologists Bulletin, v. 56, no. 10, p. 2022-2028.

Potter, R.W., and Brown, D.L., 1977, The volumetric properties of aqueous sodium chloride solutions from $0^{\circ}$ to $500{ }^{\circ} \mathrm{C}$ at pressures up to 2,000 bars based on a regression of available data in the literature: U.S. Geological Survey Bulletin 1421-C, 36 p.

Scheidegger, A.E., 1974, The physics of flow through porous media, 3d ed.: Toronto, Canada, University of Toronto Press, p. 78-80.

Skrivan, J.A., and Karlinger, M.R., 1980, Semi-variogram estimation and universal kriging program: U.S. Geological Survey Computer Program Documentation Users Manual, $98 \mathrm{p}$.

Srivastava, R.C., and Avasthi, P.K., 1975, Non-equilibrium thermodynamics of thermo-osmosis of water through kaolinite: Journal of Hydrology, v. 24 , no. 1-2, p. 111-120.

Teller, R.W., and Chafin, D.T., 1984, Selected drill stem test data for the Upper Colorado River Basin: U.S. Geological Survey Water-Resources Investigations Report 84-4146, $112 \mathrm{p}$.

Thackston, J.W., McCulley, B.L., and Preslo, L.M., 1981, Ground-water circulation in the western Paradox basin, Utah, in Weigand, D.L., ed., Geology of the Paradox basin: Denver, Rocky Mountain Association of Geologists--1981 Field Conference, p. 201-225.

Todd, D.K., 1959, Ground water hydrology: New York, John Wiley, 336 p.

Walpole, R.E., and Myers, R.H., 1978, Probability and statistics for engineers and scientists: New York, MacMillan, 580 p.

Weiss, Emanue1, 1982, A model for the simulation of flow of variable-density ground water in three-dimensions under steady-state conditions: U.S. Geological Survey Open-File Report 82-352, 59 p. 1985 , Evaluating the hydraulic effects of changes in aquifer elevation using curvilinear coordinates: Journal of Hydrology, v. 81, p. 253-275. 1986, Ground-water flow in the Navajo Sandstone in parts of Emery, Grand, Carbon, Wayne, Garfield, and Kane Counties, southeast Utah: U.S. Geological Survey Water-Resources Investigations Report 86-4012, 41 p. 1987, Boundary integral-equation-method modeling of a regional aquifer using geostatistics, in Proceedings of the Solving Ground Water Problems With Models Conference and Exposition--Vol. 2, Session X, Ground water modeling associated with nuclear waste disposal: Dublin, Ohio, National Water Well Association, p. 1,501-1,522. [Conference on Solving Ground Water Problems With Models, Denver, Colo., February 10-12, 1987]

Wengerd, S.A., and Matheny, M.L., 1958, Pennsylvanian system of the Four Corners region: American Association of Petroleum Geologist Bulletin, v. 42 , no. 9 , p. 2048-2106.

Yakowitz, S.J., and Szidarovszky, F., 1985, A comparison of kriging with nonparametric regression methods: Journal of Multivariate Analysis, v. 16 , no. 1, p. 21-53. 
SUPPLEMENTAL STATISTICAL DATA 


\section{A. Kriging}

In this section, one theoretical semivariogram was selected as a model for the equivalent freshwater heads of the sandstone and red-bed aquifer and one theoretical semivariogram was selected as the model for the equivalent freshwater heads of the limestone and dolomite aquifer. Each theoretical semivariogram was based on empirical semivariograms of equivalent freshwaterhead measurements, each was used to determine variance of the measurement errors, and each was used to interpolate equivalent freshwater-head measurements to a regular grid. The interpolation was done using a kriging program of Skrivan and Karlinger (1980). For an explanation of ordinary kriging theory (used for data without a regional trend), see Clark (1979); and for a more general explanation, including universal kriging, see Journel and Huijbregts (1978).

In the development of the theory of kriging, the regionalized variable-for example, the equivalent freshwater head in the sandstone and red-bed aquifer as a function of position--is interpreted as a particular realization of a random function. This interpretation is not realistic, because only one value of equivalent freshwater head exists in the sandstone and red-bed aquifer at each point in the aquifer. For an alternative development of the kriging results that avoids this somewhat unsatisfactory assumption, see Kafritsas and Bras (1981). Using ideas of the original development of the kriging theory, each measurement corresponds to one realization of a random variable. Because each interpolation is a weighted sum of measurements, each interpolation also is a realization of a random variable; nearby data usually are weighted more heavily than distant data. The weights are determined by the kriging calculation, which uses the autocovariance structure and the regional trend, if it exists. The autocovariance structure is displayed in a graphical form called an empirical-isotropic semivariogram that can be made from the data:

$$
\gamma(\Delta x)=\frac{1}{2 M} \sum_{i=1}^{M}\left[h_{i}(x+\Delta x)-h_{i}(x)\right]^{2} ;
$$

where $\gamma(\Delta x)$ is the value of the empirical semivariogram for the separation distance $\Delta x$.

$M$ is number of pairs of measurements separated by the distance $\Delta x$; and $h(x)$ is a measurement of the regionalized variable at the location $x$.

The empirical semivariogram bears a similar relation to the semivariogram that a histogram does to a probability distribution. Under the assumption of "stationarity," which assumes that the average equivalent freshwater head in any area is the same as the average equivalent freshwater head in any other area, the semivariogram is the variance of equivalent freshwater-head differences as a function of separation.

The semivariogram plays a central role in the kriging process almost the same as the probability distribution plays in statistical applications. The steps in the ordinary kriging process, outlined in Skrivan and Karlinger (1980), are: 
- An empirical semivariogram is made from data much as a histogram is made from data. Based on the empirical semivariogram, the functional form of a theoretical semivariogram is selected from several different functional forms; parameters for the functional form also are selected.

- The theoretical semivariogram is used to estimate data values in a validation procedure. Validation consists of using $N-1$ of the $N$ data points to predict the $N$ th data point until all $N$ data points are predicted. When the root-mean-square error of the validation procedure is minimized by a trial and error adjustment of parameters and other conditions are satisfied, then the best parameters for the theoretical semivariogram are established.

- The best semivariogram of the validation procedure is taken as the model of the autocovariance structure of the areally distributed data. Using the best theoretical semivariogram as a model for the autocovariance structure of all the data (measured as well as unmeasured), interpolations are done. An estimate of the interpolation error is given for each interpolation point.

The following description explains how the equivalent freshwater heads in the sandstone and red-bed aquifer were interpolated using the work of Skrivan and Karlinger (1980) and Karlinger and Skrivan (1980); it is not intended to explain the theory of kriging or to cover the improvements in kriging applications since 1980 .

Three empirical semivariograms of the 78 equivalent freshwater head measurements in the sandstone and red-bed aquifer are shown in figure 18: the isotropic, the east-west, and the north-south. One theoretical semivariogram of the spherical type that best characterizes the aquifer equivalent freshwater heads also is shown. A "dip" exists in each empirical semivariogram that cannot be fit by any of the theoretical semivariograms in Skrivan and Karlinger (1980). The "dip" occurs before the maximum in each semivariogram; it is characterized by a decrease in the value of the semivariogram with increasing point separation. After excluding possible outliers in the data, other empirical semivariograms were made. Because the exclusion of outliers did not eliminate the "dip" or result in semivariograms of more nearly theoretical form, all data were used for subsequent analysis.

Anisotropy is shown in figure 18 by the difference between the east-west semivariogram and the north-south semivariogram. They have different sills (asymptotic values) and possibly different ranges (distances over which equivalent freshwater heads are correlated). The apparently unbounded eastwest semivariogram indicates a possible east-west regional trend in the data; however, this trend is uncertain because the dashed part of the semivariogram is not reliable.

Considerable effort was expended in an attempt to remove this anisotropy. Possible outliers in the equivalent freshwater-head data were removed, and semivariograms were redone. Anisotropy persisted in the additional semivariograms. In another attempt to remove the anisotropy, a drift (regional trend) of the form $a+b x+c x^{2}$ was fit to the data; $x$ is distance along the east-west direction. Removing anisotropy by removing a regional trend is suggested in David (1977, p. 274). Empirical semivariograms were made using the residuals about the drift. The resulting east-west empirical semivariogram had a sill of $7 \times 10^{5} \mathrm{ft}^{2}$; however, the north-south semivariogram still had a sill of $16 \times 10^{5} \mathrm{ft}^{2}$, and anisotropy persisted. 


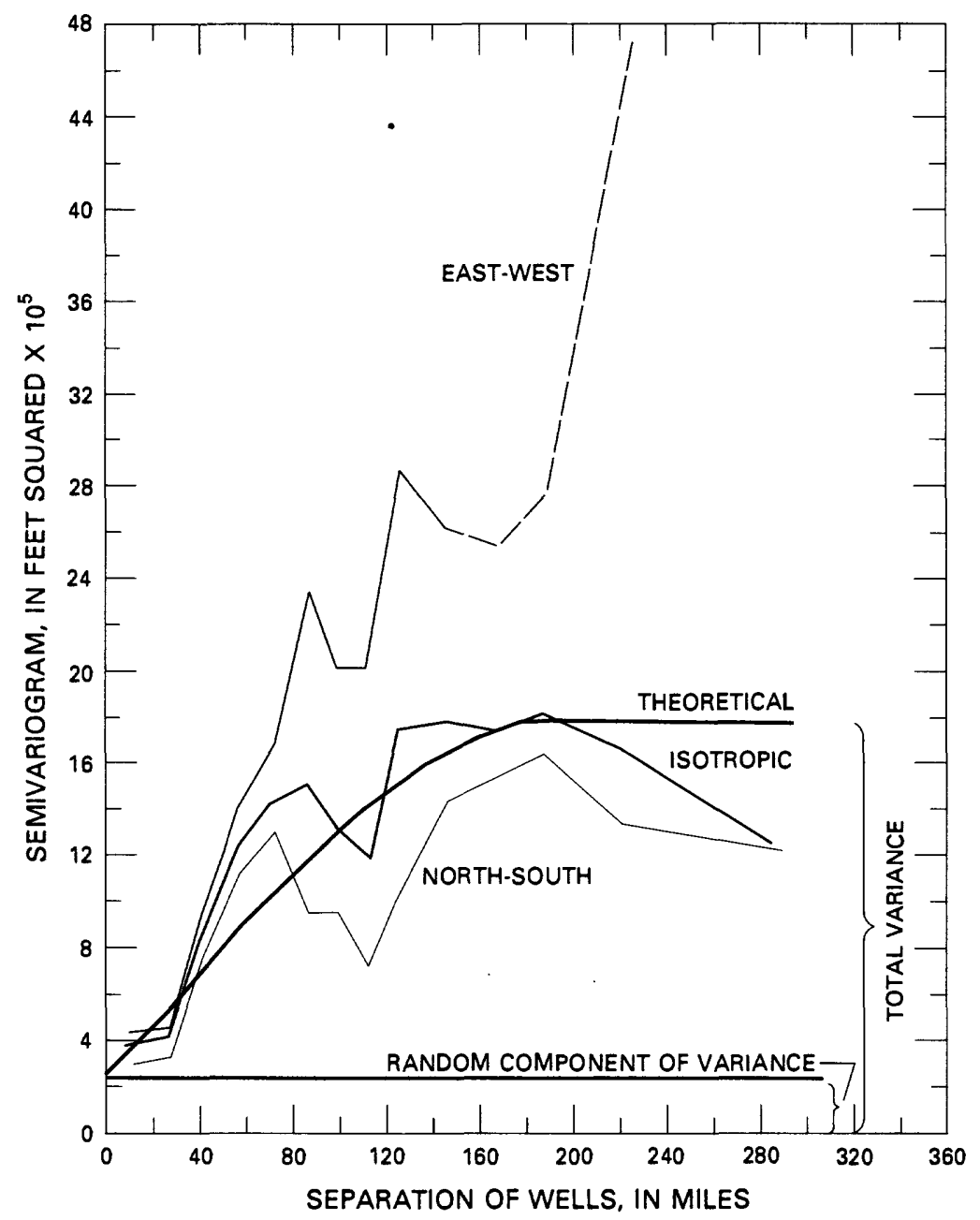

Figure 18.--Semivariograms of equivalent freshwater-head data for the sandstone and red-bed aquifer (modified from Weiss, 1987)

Finally a drift containing only statistically significant terms was used: drift $=a x^{2}+b x y+c y^{2}$. Anisotropy persisted in the semivariograms of the residuals.

Because of the persistence of anisotropy in the empirical semivariograms and because the Skrivan and Karlinger (1980) interpolation subroutine of the program can accommodate only isotropic models, the following interpolation using isotropic semivariograms to characterize the covariance structure of the data cannot be wholly satisfactory. The failure of empirical semivariograms to fit simple theoretical semivariogram models is a common experience in kriging. Often, as in this instance, a simple model is used even though the empirical semivariograms do not fit a simple model, thereby compromising the validity of the kriging results. The degree to which the results are compromised is not known.

Nonparametric-interpolation methods that do not use semivariograms have been suggested (Henley, 1981). (For a comparison between kriging and nonparametric-interpolation methods, see Yakowitz and Szidarovszky, 1985.) 
Initially, a Gaussian semivariogram was selected for use in an attempt to fit the flatness of the empirical semivariograms near the origin; however, the spherical semivariogram shown in figure 18 proved to be superior statistically in the validation procedure. The parameters for the spherical semivariogram that best predict measured equivalent freshwater heads are:

- Range $200 \mathrm{mi}$.

- Nugget $2 \times 10^{5} \mathrm{ft}^{2}$.

- Sill $18 \times 10^{5} \mathrm{ft}^{2}$.
Range is the separation at which the semivariogram becomes flat.

Nugget is the value of the semivariogram at zero separation.

Sill is the value of the semivariogram where it is flat.

The statistics for the predictions of measurements made using the spherical-semivariogram model defined above are:

- Averaging kriging error

- Root-mean-square error

- Reduced root-mean-square error 1.03 .

The errors of the validation step are the differences between the measured equivalent freshwater head at each location of a measurement and the equivalent freshwater head predicted at that location when all other measured equivalent freshwater heads are used in the prediction calculation. The objective of the validation step is to select the theoretical semivariogram that minimizes the root-mean-square error while keeping the average error near zero and the reduced root-mean-square error near one. The reduced root-mean-square error is the root-mean-square of the error of interpolation divided by the standard deviation of the error of interpolation. The error of interpolation (also called error, above) is the interpolated value minus the true value at a point of interpolation.

If the theoretical semivariogram is accepted as an accurate characterization of the autocovariance structure of the equivalent freshwater-head data of the sandstone and red-bed aquifer, then an estimate of the random component in the equivalent freshwater-head data can be made. The value of the semivariogram for points of zero separation is zero, but the semivariogram is not necessarily continuous at zero. If the semivariogram is not continuous at zero, as is the case for equivalent freshwater heads in the upper aquifer in rocks of Paleozoic age, then the distribution of equivalent freshwater heads (the regionalized variable) is viewed as discontinuous at all points. The magnitude of the discontinuity is called the nugget in geostatistics. The discontinuity is caused mostly by the process error in the equivalent freshwater-head data (see the "Process Error and Model Error" section), which includes measurement and data-handling errors and the error made by disregarding vertical gradients in equivalent freshwater-head gradient.

A summary of statistics for the equivalent freshwater-head measurements in both aquifers is listed in table 6 . Because the nugget approximates the random component of the variance, the ratio of the nugget to the variance indicates that about 15 percent of the variance in sample values is random. The values of the nugget and the sill for the equivalent freshwater-head data of both aquifers were almost identical, which indicates that the values were independent of sample size or sample choice; consequently, the value of the nugget was almost totally due to process error and not due to statistical shortcomings such as small sample size or nonrandom sample choice. 
Most of the above discussion is approximate because the assumptions of kriging are not completely satisfied. If all the assumptions of kriging were satisfied, the variance of the samples from both aquifers would be equal to the value of the sill; for both aquifers, the variance is not equal to the sill (table 6).

Table 6.--statistical summary of equivalent freshwater-head measurements for the sandstone and red-bed aquifer and limestone and dolomite aquifer

\begin{tabular}{|c|c|c|}
\hline \multirow[b]{2}{*}{ Statistic } & \multicolumn{2}{|c|}{ Equivalent freshwater head } \\
\hline & $\begin{array}{l}\text { Sandstone and } \\
\text { red-bed aquifer }\end{array}$ & $\begin{array}{l}\text { Limestone and } \\
\text { dolomite aquifer }\end{array}$ \\
\hline $\begin{array}{l}\text { Number of measurements } \\
\text { Mean } \\
\text { Variance }\end{array}$ & $\begin{array}{l}79 \\
5,355 \text { feet } \\
14 \times 10^{5} \text { feet squared }\end{array}$ & $\begin{array}{l}179 \\
4,834 \text { feet. } \\
12 \times 10^{5} \text { feet squared. }\end{array}$ \\
\hline \multicolumn{3}{|c|}{ Theoretical semivariogram type and parameters } \\
\hline $\begin{array}{l}\text { Type } \\
\text { Range (correlation length) } \\
\text { Nugget (random component of } \\
\text { theoretical variance) } \\
\text { Sill (theoretical variance) }\end{array}$ & $\begin{array}{l}\text { Spherical } \\
200 \text { miles } \\
2 \times 10^{5} \text { feet squared } \\
18 \times 10^{5} \text { feet squared }\end{array}$ & $\begin{array}{l}\text { Spherical. } \\
100 \text { miles. } \\
2 \times 10^{5} \text { feet squared. } \\
17 \times 10^{5} \text { feet squared. }\end{array}$ \\
\hline
\end{tabular}

For each interpolation, the standard deviation of the quantity, true equivalent freshwater head minus interpolated equivalent freshwater head, or the standard deviation of the error of interpolation is shown in figures 7 and 8. Several factors make up the standard deviation of the error of interpolation (see Skrivan and Karlinger, 1980, p. 14). In the instance of no drift and no error of measurement, the standard deviation of the error of interpolation is:

$$
\sqrt{\sum_{i=1}^{N} \lambda_{i} \gamma_{t h}\left(\Delta x_{i j}\right)}
$$

where $N$ is the number of measurements;

$i$ refers to a measurement;

$j$ refers to the interpolation location;

$\lambda_{i}$ is the weight from kriging of the $i$ th measurement for the $j$ th interpolation, $\sum_{i=1}^{N} \lambda_{i}=1$;

$\gamma_{t h}\left(\Delta x_{i j}\right)$ is the value of the theoretical semivariogram for the distance between the location of the $i$ th measurement and the location of the $j$ th interpolation; and $\Delta x_{i j}$ is the distance between the location of the ith measurement
and the location of the jth interpolation.

For this report, the standard deviation of the error of interpolation is the square root of the weighted sum of the theoretical semivariogram evaluated for each possible pairing of a measurement with the interpolation location. 
A basic assumption of kriging is that an estimated value can be obtained using a weighted linear combination of measurements, the additivity assumption (Journel and Huijbregts, 1978, p. 199). This requirement arises because the kriging calculation assumes each interpolated value is a weighted average of measurements. The weighted average of transmissivity measurements would not be representative of the transmissivity value at an interpolation point, because measurement of small transmissivity values are more characteristic of transmissivity distributions than measurements of large transmissivity values. However, the weighted average of the logarithm of transmissivity values would be representative of the logarithm of transmissivity values at an interpolation point.

The major weightings, determined by kriging for equivalent freshwaterhead measurements in the sandstone and red-bed aquifer for the grid point defined by the intersection of latitude $39^{\circ} 4^{\prime}$ and longitude $111^{\circ} 30^{\prime}$ are shown in figure 19. Note that the nearest measurement of $8,220 \mathrm{ft}$ has a weight of 0.44. Furthermore, the 4,580-ft measurement is closer to the extrapolated point than the 4,290-ft measurement, but the 4,290-ft measurement has a larger weight $(0.13$ versus 0.01$)$; this is an example of the screening effect that is characteristic of kriging extrapolations. (The 4,580-ft measurement is screened by the $8,220-\mathrm{ft}$ measurement.) Some weights are negative, which is allowed; approximately 93 percent of the value of the extrapolated point is determined by the three measurements having the largest weights. The fourth largest weight is less than 2 percent. Nearby unscreened points are more heavily weighted compared to screened points and distant points. Some recent kriging algorithms only use nearby points; whereas, Skrivan and Karlinger (1980) use all measurements in the calculation of the interpolated value.

The procedures to decide the best theoretical semivariogram or to decide that a regional trend needed to be removed were not objective. To see the results of different decisions, no regional trend and two different regional trends were assumed, and the maximum interpolation difference was approximately 8 percent among these three approaches. Thirty percent was the maximum difference in the standard deviation of the error of interpolation for the equivalent freshwater heads of the sandstone and red-bed aquifer. Similar differences might be expected in the other applications of kriging in this report.

\section{B. Process Error and Model Error}

An adequate model is one that is likely to predict unmeasured equivalent freshwater heads as well as or better than additional measurements. This can be determined when the model has not been calibrated. Simulated equivalent freshwater heads from an uncalibrated model are likely to be randomly distributed about true equivalent freshwater heads, which is the result of a perfect measurement, perfect data handling, and taking full account of vertical gradients in equivalent freshwater heads. For a true equivalent freshwater head, the process error is zero. The difference between the value of equivalent freshwater head mapped during this study and the actual value that exists at that mapped location, perhaps at the midpoint of the aquifer, is called the process error in this report. 


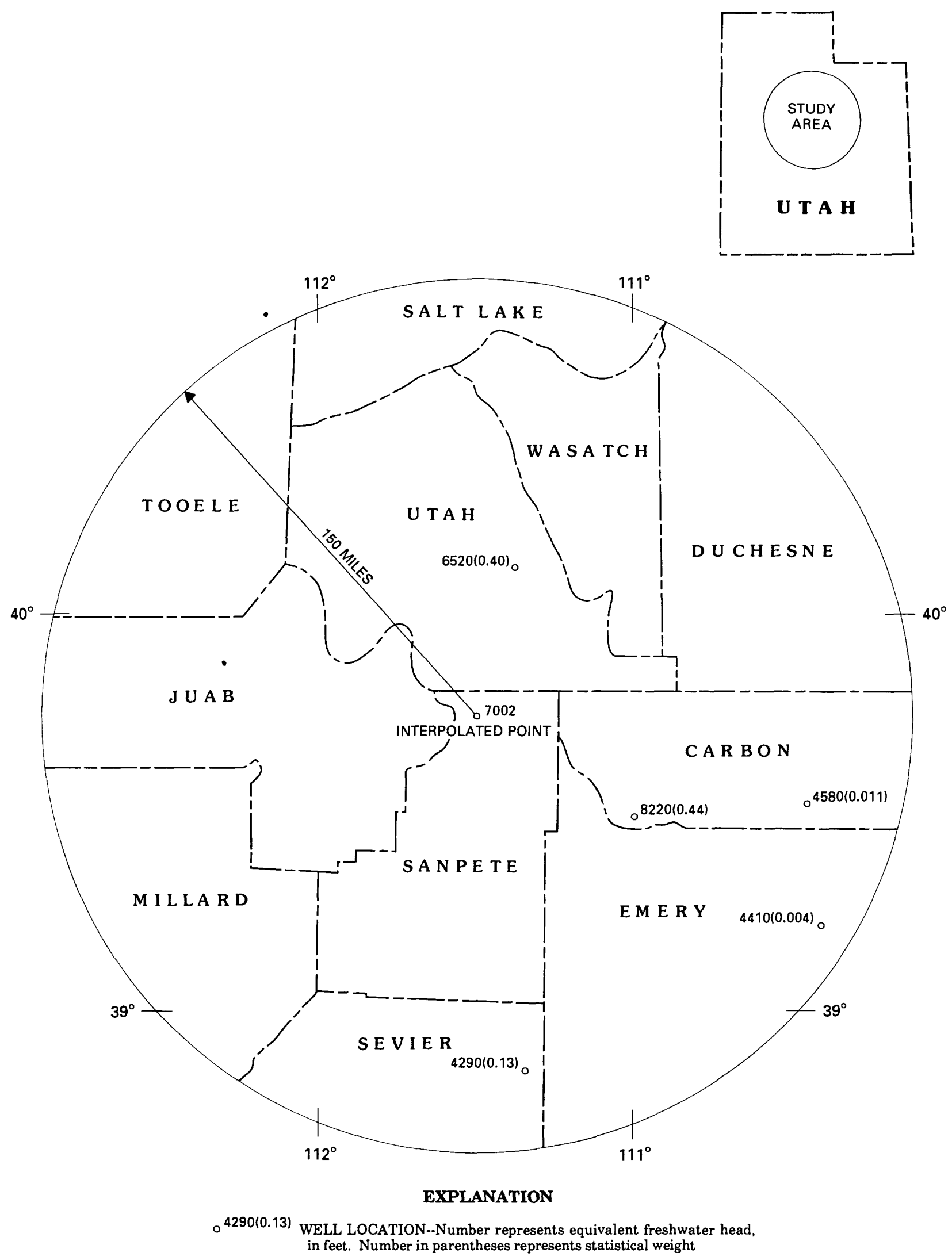

Figure 19.--Measurements of equivalent freshwater head and statistical weights for interpolation near the northwesternmost interpolated point. 
To determine model adequacy, the root-mean-square model error is compared to the root-mean-square process error. If the root-mean-square process error is greater than the root-mean-square model error, then the model is adequate. The following paragraphs describe how to compute these two errors when no calibration has taken place.

A processed equivalent freshwater head minus the corresponding simulated equivalent freshwater head is called the residual, $r$. A true equivalent freshwater head (the result of a perfect processing) minus the corresponding processed equivalent freshwater head is called the process error, e. A simulated equivalent freshwater head minus the corresponding true equivalent freshwater head is called the model error, $e$.

Using these definitions:

$$
-r=e+\tilde{e}
$$

If the process error is independent of the model error, then the covariance of the process error and model error is:

and

$$
\langle\tilde{e} \bar{e}>0
$$

$$
\left\langle r^{2}\right\rangle=\left\langle e^{2}\right\rangle+\left\langle\tilde{e}^{2}\right\rangle
$$

Brackets mean average of what is inside the brackets.

To see the plausibility of $\langle\tilde{e} \tilde{e}\rangle=0$ for an uncalibrated model, consider $e=h_{s}-h_{f}$, where $h_{s}$ is simulated equivalent freshwater head and $h_{t}$ is true
equivafent freshwater head.

$$
\langle\tilde{e} \tilde{e}\rangle=\left\langle e h_{s}\right\rangle-\left\langle e h_{t}\right\rangle
$$

Process error is randomly distributed about true equivalent freshwater head and $\left\langle e h_{t}\right\rangle=0$. If the model were well calibrated, then there would be a correlation between process error and simulated equivalent freshwater head because calibration brings simulated equivalent freshwater heads closer to processed equivalent freshwater heads. If the model is uncalibrated, then process error could be randomly distributed about simulated equivalent freshwater head as it is about true equivalent freshwater head and $\left\langle e h_{s}>=0\right.$. Therefore, $\langle e e\rangle=0$ is reasonable.

Now $\left\langle r^{2}\right\rangle$ and $\left\langle e^{2}\right\rangle$ will be estimated from available data, then $\left\langle\tilde{e}^{2}\right\rangle$ will be calculated. Finally, $\left\langle e^{2}\right\rangle$ and $\left\langle e^{2}\right\rangle$ will be compared. For the flow model of the sandstone and red-bed aquifer, $\left\langle r^{2}\right\rangle=(628 \mathrm{ft})^{2}$, which is taken from table 5. Assuming the average process error for the values of equivalent freshwater head in the sandstone and red-bed aquifer is approximately zero, the nugget of their theoretical semivariogram is approximately the mean-square process error or $\left\langle e^{2}\right\rangle=(447 \mathrm{ft})^{2}$, which is the nugget 1isted in table 8 . Using these two numbers, the mean-square-model error, $\left\langle e^{2}\right\rangle$, equals $(441 \mathrm{ft})^{2}$. The approximate equality of the root-mean-square model error and the process error indicates that the flow model of the sandstone and red-bed aquifer could estimate equivalent freshwater-head values as well as additional processes of the type that were done onsite and in the analysis of this report. 
The flow model of the limestone and dolomite aquifer had a root-meansquare model error of $689 \mathrm{ft}$; equivalent freshwater-head measurement in the limestone and dolomite aquifer had a root-mean-square process error of $447 \mathrm{ft}$. The larger root-mean-square model error indicates that the model could not estimate equivalent freshwater-head values as well as additional processes of the type that were done.

\section{Equivalent Freshwater-Head Differences between Aquifers}

The measured equivalent freshwater heads of both aquifers were interpolated to a regular grid. The regular grid of interpolated equivalent freshwater-head measurements gave values of equivalent freshwater head throughout parts of the modeled area in both aquifers where no equivalent freshwater-head measurements existed; the values were at the same locations allowing vertical equivalent freshwater-head differences to be calculated at grid points. A fundamental concern is the degree of certainty that can be attributed to the vertical equivalent freshwater-head differences given the standard deviation of the error of interpolation shown in figures 10 and 11. This section is an attempt to identify areas of more certain vertical equivalent freshwater-head difference and areas of less certain vertical equivalent freshwater-head difference. .

The assignment of a "more certain" or a "less certain" equivalent freshwater-head difference is based on the unproven assumption that the errors made in interpolation to a point in the upper aquifer are uncorrelated or are correlated positively with the errors made in interpolation to the underlying point in the lower aquifer. The approximate result of the following argument is that the largest equivalent freshwater-head differences shown in figure 15 are in areas of "more certain" vertical equivalent freshwater-head differences.

In the theory of kriging, the regionalized variable--the equivalent freshwater head in the sandstone and red-bed aquifer as a function of position--is interpreted as a particular realization of a random function. Each measurement corresponds to one realization of a random variable; because each interpolation, $h_{i}$, at the ith grid point is a weighted sum of measurements, each interpolation is a realization of a random variable. The calculation of $\operatorname{var}\left(h_{i}-h_{i}\right)$, the variance of the true equivalent freshwater head at the interpolation point minus the predicted equivalent freshwater head, is a by-product of the kriging interpolation. Now an argument will be made that a "more certain" or "less certain" measure of probability can be assigned to interpolated vertical equivalent freshwater-head differences.

A theorem that relates the variances of two random variables with the variance of their difference (see Walpole and Myers, 1978) follows:

$$
\operatorname{Var}\left(e_{u}^{-e_{1}}\right)=\operatorname{Var} e_{u}-\operatorname{var} e_{1}-2 \operatorname{Covar}\left(e_{u}, e_{1}\right) ;
$$

where $e_{u}$ is the interpolation error in the upper aquifer; and

$e_{l}^{u}$ is the interpolation error in the lower aquifer. 
Because $e^{-e} e_{l}=\Delta h-\Delta h$, where $\Delta h$ is the true vertical equivalent freshwater-head difference, and $\Delta \hat{h}$ is the interpolated vertical equivalent freshwater-head difference, the variance of the true vertical equivalent freshwater-head difference minus the predicted vertical equivalent freshwaterhead difference can be calculated, provided that the covariance of the errors in each aquifer is known. Although a positive correlation should exist between the measured equivalent freshwater heads in the upper and the lower aquifers, a positive correlation does not necessarily exist between the interpolation errors. To determine the correlation between the interpolation error at a point in the upper aquifer and the interpolation error at the underlying point in the middle aquifer is impossible because the interpolation errors are not known; only the variance of the interpolation errors is known. If the interpolation errors were known, many realizations would be needed to get a good estimate of the correlation at a point.

Assuming a positive or zero correlation of the interpolation errors:

$$
\operatorname{Var}(\Delta h-\Delta \hat{h}) \leq \operatorname{Var} e_{u}+\operatorname{Var} e_{1} \equiv \sigma^{2} .
$$

Thus, a bound on the variance of the true vertical equivalent freshwater-head difference minus the predicted vertical equivalent freshwater-head difference is obtained. Recall that $\Delta \hat{h}$ and $\Delta h$ are random variables in regionalized variable theory; hence, a probability statement that does not depend on an assumed distribution can be made via Chebychev's theorem (see Walpole and Myers, 1978):

$$
P[\Delta \hat{h}-2 \sigma<\Delta h<\Delta \hat{h}+2 \sigma]>3 / 4 \text {. }
$$

Where $\overline{\Delta h-\Delta \bar{h}}=0$ was used, the average is zero because kriging is an unbiased estimator of the true equivalent freshwater-head difference. The above probability statement means that the probability is greater than 75 percent that the true vertical equivalent freshwater-head difference is in the range defined by the predicted vertical equivalent freshwater-head difference minus $2 \sigma$ and the predicted vertical equivalent freshwater-head difference plus $2 \sigma$. The calculation of the range for each grid point shows that zero is included in each range.

If a normal probability distribution is assumed for the distribution of $\Delta h$, then a probability statement having a smaller range can be written:

$$
P[\Delta \hat{h}-\sigma<\Delta h<\Delta \hat{h}+\sigma] \sim 0.67 \text {. }
$$

Only 14 grid points have zero excluded from their ranges. These 14 grid points are said to be points of "more certain" vertical equivalent freshwaterhead difference. All the other grid points are said to be points of "less certain" vertical equivalent freshwater-head difference. 